\title{
LPG BURNERS FOR WEED CONTROL
}

\author{
M. Raffaelli, C. Frasconi, M. Fontanelli, L. Martelloni, A. Peruzzi
}

\begin{abstract}
This article reports on the results of a study carried out on three prototypes of open flame burners for thermal weed control. Their performance is reported in terms of flame temperature and length, in order to ascertain the best ratio between primary and secondary air, and liquefied petroleum gas (LPG) consumption.

To find the best ratio between primary and secondary air, the length and temperature of the flame were recorded for each of the three burners, examined by varying the inlet sections of the primary air and secondary air. The data on temperature and the flame length of each burner were processed using multiple regression analysis. The LPG consumption was determined with one of the burners using 10 different pressures in combination with three nozzles. The data obtained were subjected to non-linear regression using two gaseous outflow models.

The various combinations of primary and secondary air inlet sections affected the values of the flame length and temperature. In general, the best combinations of primary and secondary air inlet for flame temperature did not correspond to those for flame length. However, this experiment showed that the inlet of secondary air is critical for the performance of this type of burner, in terms of flame temperature. The fuel consumption trial showed that the model proposed for the gaseous outflow is suitable for describing the values of LPG consumption collected during the trial.
\end{abstract}

Keywords. Flame temperature and length, Flame weeding, LPG consumption, LPG flame burner.

$\mathrm{F}$ lame weeding is used to control weeds with heat generated by a flame. Plants are exposed to a flame generating ultra-high temperatures that produce cellular death due to the initial thermal disruption of the cellular membranes rapidly followed by dehydration of the affected tissue (Ellwanger et al., 1973). Tissue dehydration subsequent to thermal membrane disruption is an important factor in cell death (Ellwanger et al., 1973).

Flame weeding has been applied on a large scale since the 1940s in the United States and is still the focus of research (Raffaelli et al., 2010; Ulloa et al., 2010; Raffaelli et al., 2011; Ulloa et al., 2011 Datta and Knezevic, 2013; Knezevic et al., 2013). The use of an efficient purpose-built burner is essential for good weed control, so the need to develop suitable flamers and efficient burners remains (Carter et al., 1960; Laguë et al., 1997; Ascard, 1998; Kang, 2001; Raffaelli et al., 2013).

A burner is a device that burns solid, liquid, or gaseous fuels in order to produce heat. It introduces fuel, suitably prepared, into a combustion chamber, combines the fuel with air, the mixture is ignited and combusts. Currently all

Submitted for review in May 2014 as manuscript number MS 10762; approved for publication by the Machinery Systems Community of ASABE in July 2015.

The authors are Michele Raffaelli, Professor, Christian Frasconi, Researcher, Marco Fontanelli, Researcher, Andrea Peruzzi, Professor, Department of Agriculture, Food and Environment, University of Pisa, Pisa, Italy; Luisa Martelloni, Postdoctoral Fellow, Centro di Ricerche Agro-Ambientali "Enrico Avanzi", University of Pisa, San Piero a Grado (PI), Italy. Corresponding author: Michele Raffaelli, Department of Agriculture Food and Environment, University of Pisa, Via del Borghetto, 80, 56124 Pisa, Italy; phone: 0039-050-2218947; e-mail: michele.raffaelli@unipi.it. burners for weed control are fuelled by liquefied petroleum gas (LPG). The use of LPG is clean-burning, and LPG generates a stable flame for easy adjustment, achieves the required working pressure with simple constructive solutions, keeps the fuel safely without special and expensive tanks, and is affordable.

From a structural point of view, the most common flame burners using gaseous fuels can be distinguished according to the mix between air and gas (Galbiati, 2005) Diffusion burners, in which the mix between gas and air occurs directly in the combustion chamber during combustion, produce a long and bright flame. For premix burners, all the air or a part of it (primary air) is mixed with the gas before being introduced into the combustion chamber. In the case of a mixture, the remaining partial air (secondary air) enters subsequently during combustion. Comparing diffusion burners and premix burners, for premix burners combustion is quicker, the flame is shortened and loses brightness with a considerable increase in temperature (Galbiati, 2005).

Premix burners can in turn be divided into air-intake burners and blown-air burners (Galbiati, 2005). In airintake burners (also known as atmospheric burners), the fuel gas and air are mixed in an external mixer by the Venturi effect. In the blown-air burners, the air is introduced and mixed with the gas by centrifugal force. Blown-air burners have quite complex constructive schemes, since the devices are necessary for the regulation of gas and air flows in order to obtain, in the different operating conditions, the most suitable mixing ratio.

Equipment for flame weeding is provided with atmospheric burners. This equipment can be divided into two broad categories: open flame burners and infrared burners (Ascard, 1998). The open flame burners can be divided into 
burners that use the LPG in a gaseous phase (most common) and burners that use LPG in the liquid phase also called "self-vaporizing" (de Rooy, 1992). Open flame burners have a cylindrical or truncated-conic shape or prismatic or a truncated-pyramidal shape.

Open flame burners working with LPG in a gaseous phase with a prismatic or truncated-pyramidal shape produce a well-defined and controllable flame suitable for homogeneous treatment on defined targets. These types of burners are easy to construct and are very robust and thus particularly suitable for flame weeding.

This article provides the results of a study carried out on three prototypes of open flame burners for flame weeding. Their performance is reported in terms of flame temperature and length, highlighting the best ratio between primary and secondary air, and in LPG consumption.

\section{Materials ANd Methods}

\section{THE BURNERS}

Three prototypes of open-flame burners were designed and built by MAITO S.R.L (Arezzo, Italy) in co-operation with the Department of Agriculture, Food and Environment of the University of Pisa.

The main characteristics of the three burners, henceforth called burner 1, 2, and 3 (figs. 1, 2, and 3), are shown in table 1 . For all three burners, the secondary air enters the combustion chamber via the Venturi effect in the restricted section of the shield. Burners 1 and 2 have two openings with a rectangular section (one on each side of the cover) $155 \mathrm{~mm}$ in width and $2.7 \mathrm{~mm}$ in height. Burner 3 allows for a secondary air inlet and thus has a series of 98 holes (49 on each side of the shield) with a diameter of $1.4 \mathrm{~mm}$ and arranged in four rows. The input of primary air takes place upstream of the burner along the line of the LPG feeding system. Here, coaxially to the outer tube, a mixer is mounted with six side holes with a diameter of $7 \mathrm{~mm}$, inside of which the nozzle is screwed (fig. 4).
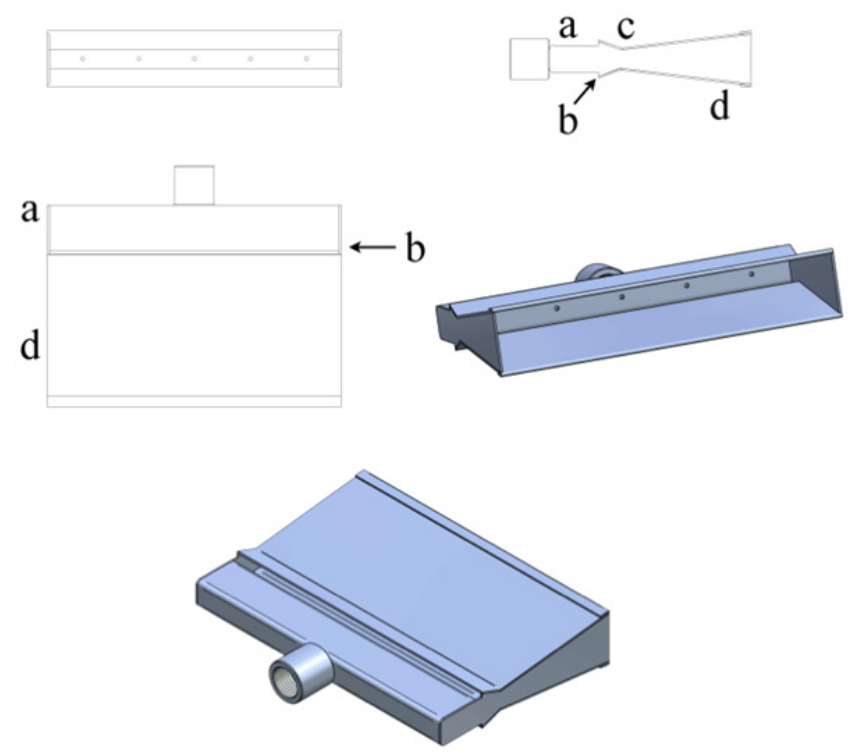

Figure 1. Burner 1: a) diffuser, b) secondary air inlet, c) shield converging section, d) shield.
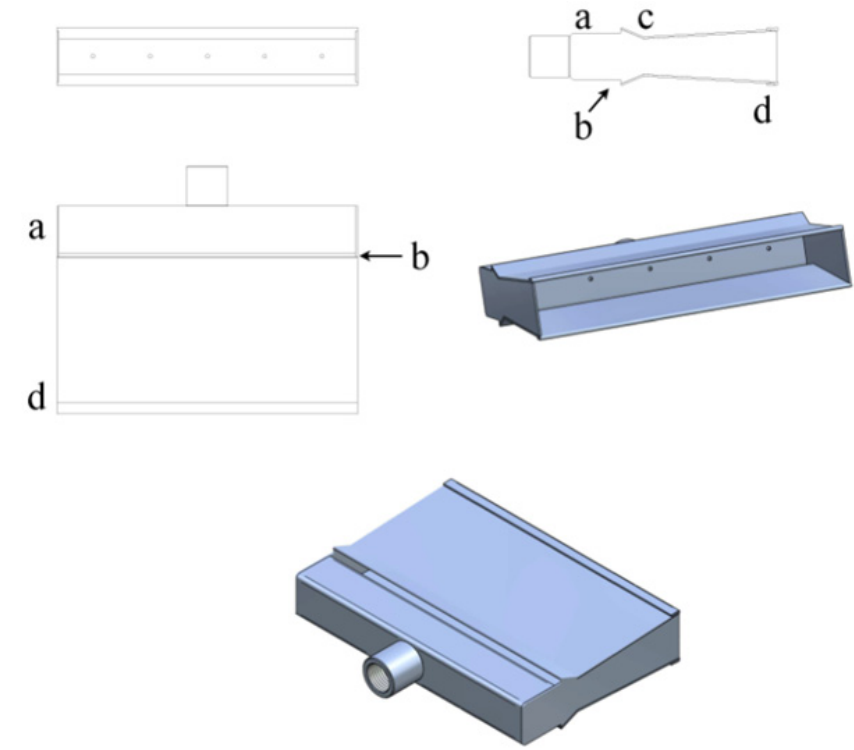

Figure 2. Burner 2: a) diffuser, b) secondary air inlet, c) shield converging section, d) shield.
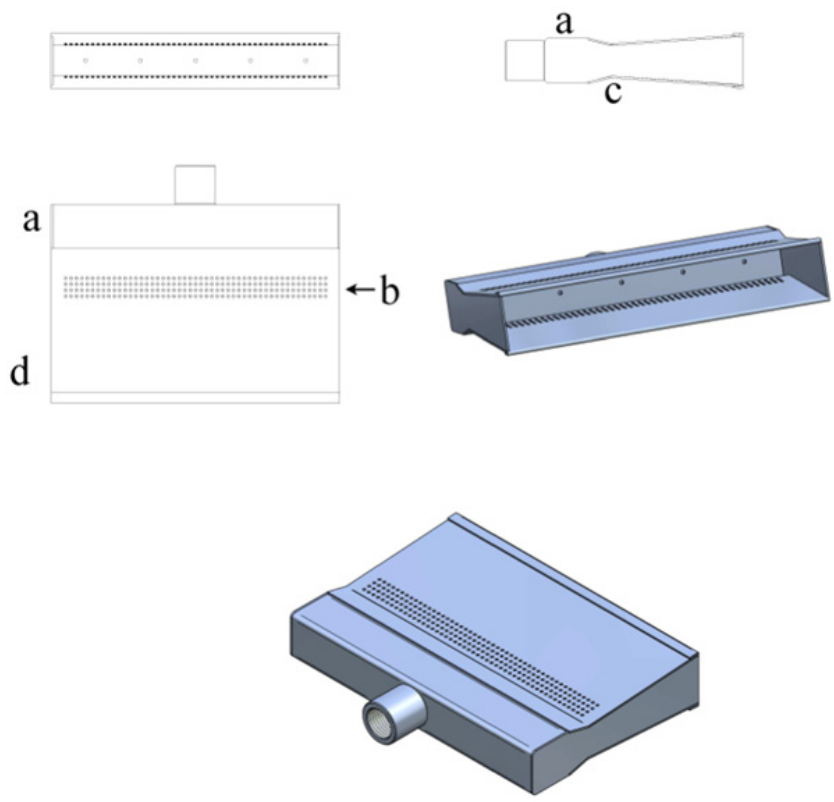

Figure 3. Burner 3: a) diffuser, b) secondary air inlet, c) shield converging section, d) shield.

\section{EXPERIMENTAL APPARATUS}

The experiment was carried out in the laboratory of Agricultural Machinery and Farm Mechanization of the Department of Agriculture, Food and Environment of the

Table 1. Main characteristics of the burners.

\begin{tabular}{lccc}
\hline \multicolumn{1}{c}{$\begin{array}{c}\text { Characteristics } \\
(\mathrm{mm})\end{array}$} & 1 & 2 & 3 \\
\cline { 2 - 4 } & 160 & 160 & 160 \\
Width & 131 & 131 & 131 \\
Length & 15 & 25 & 25 \\
Diffuser height & 158 & 158 & 158 \\
Diffuser width & 5 & 5 & 5 \\
Diffuser hole number & 2 & 2 & 2 \\
Diffuser hole diameter & 27 & 27 & 27 \\
Shield exit height & 10 & 19 & 19 \\
Shield converging section height & & &
\end{tabular}



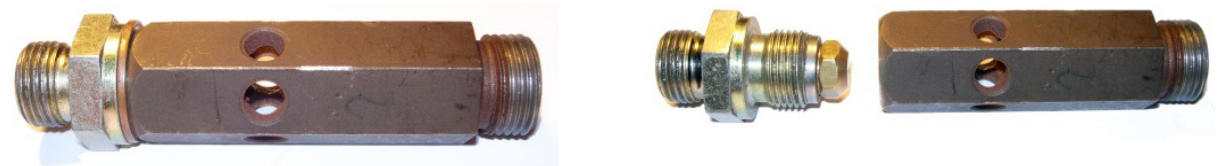

Figure 4. External mixer with the nozzle. Shown on the right are the two components before assembly, and on the left are the nozzle and mixer assembled.

University of Pisa, Italy, during 2011. The burners were mounted on a specific test bench for flaming. They were connected to a tank containing $15 \mathrm{~kg}$ of LPG, which was maintained at a constant temperature of about $25^{\circ} \mathrm{C}(298 \mathrm{~K})$ using a heat exchanger containing water heated by a common domestic burner fed by a second tank of LPG. The feeding line from the LPG tank to the burner was equipped with a pressure regulator with manometer, a flow regulator for adjusting the pilot flame, a manual valve to open and close the flow of gas to obtain the correct working pressure by bypassing the regulator of the pilot flame, and an external mixer with six side holes with a diameter of $7 \mathrm{~mm}$ with the nozzle inside (fig. 5).

Flame temperature was registered by a specific R type bifilar thermocouple (platinum-rhodium, range 600$1700^{\circ} \mathrm{C}$ ), placed $10 \mathrm{~cm}$ from the distal edge of the burner, connected to a digital thermometer. The flame length was measured by a graded reference parallel to the burner with a black background by visual direct observation and by a camera on a plane parallel to the flame. LPG consumption was determined by a balance with an accuracy of $1 \mathrm{~g}$.

\section{DETERMining THE BeSt RATIO BETWEen the SeCtions OF THE PRIMARY AND THE SECONDARY AIR}

An experimental test was carried out to identify the best ratio between primary and secondary air, which is of fundamental importance in order to obtain the complete combustion of LPG and thus obtain the highest temperatures of the flame (Galbiati, 2005). The length and the temperature of the flame were recorded for each of the three burners examined by varying the inlet sections of the primary air (holes of the external mixer) and secondary air (openings in the shield of the burner). The variations of the section of the primary air were obtained by hermetically plugging $0,2,4$ and 6 holes of the external mixer with adhesive tape. The variation in the section of the secondary air in burners 1 and 2 was made up with two devices provided with a sliding metal plate. This "guillotine" was fixed on each side of the burner. It enabled the height of the rectangular area to be varied for air intake on the shield, thus obtaining different values for the input section. In burner 3, due to the particular shape of the openings, the variations in the section of the secondary air were obtained by progressively sealing one of the four rows of holes on each side of the shield with a special adhesive aluminium tape that is resistant to high temperatures. Thus for each prototype burner, it was possible to obtain different combinations of the input sections of primary and secondary air (tables 2 and 3 ).

Each measurement was replicated three times. In order to find the best ratio between primary and secondary air section, data on the temperature and length of the flame of each burner were processed by multiple regression adopting the following second-order surface function (paraboloid).

$$
z=z_{0}+a x+b y+c x^{2}+d y^{2}+e x y
$$

where

$z=$ values of the dependent variable: temperature $\left({ }^{\circ} \mathrm{C}\right)$; flame length $(\mathrm{cm})$,

$z_{0}=$ value of $\mathrm{z}$ when both $\mathrm{x}$ and $\mathrm{y}$ are equal to 0 ,

$x=$ secondary air $\left(\mathrm{mm}^{2}\right)$,

$y=$ primary air $\left(\mathrm{mm}^{2}\right)$,

$a, b, c, d, e=$ constant coefficients.

The trials were conducted at an LPG working pressure of $0.2 \mathrm{MPa}$, and adopting an external mixer equipped with a nozzle of $0.8 \mathrm{~mm}$, which in previous experiments provided the best performance. The maximum values of the dependent variables predicted by the multiple regression analysis for each burner were compared using the confidence interval overlap test. Data were processed using SigmaPlot version 12.0, (Systat Software, Inc., 2011).

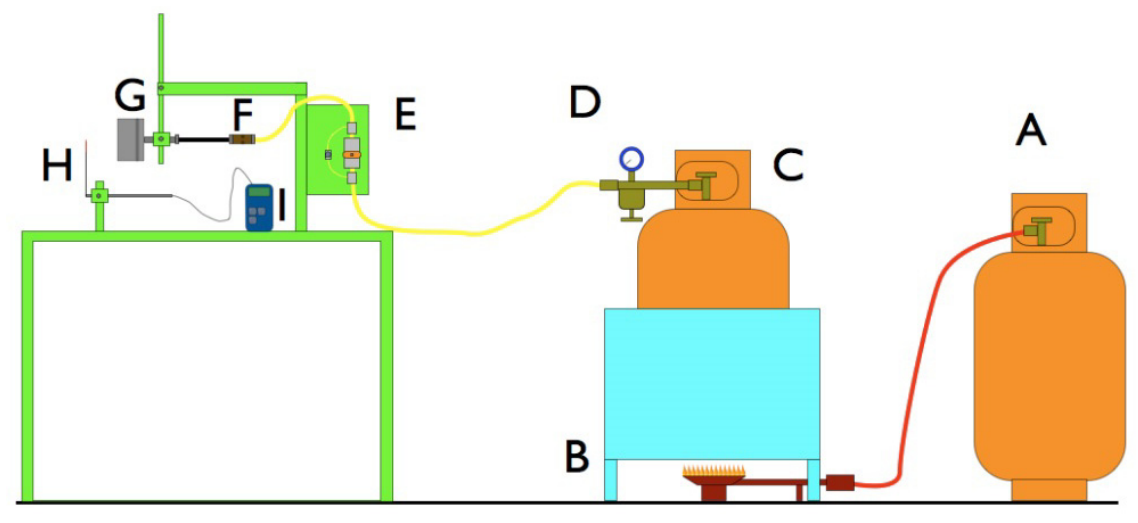

Figure 5. Experimental apparatus: A) tank of the heat exchanger, B) heat exchanger, C) burner feeding tank, D) pressure regulator and manometer, E) control board, F) external mixer, G) burner, H) thermal probe type R, I) digital thermometer. 
Table 2. Burners 1 and 2 combinations of the input sections of primary and secondary air.

\begin{tabular}{cc}
\hline Section Primary Air $\left(\mathrm{mm}^{2}\right)$ & Section Secondary Air $\left(\mathrm{mm}^{2}\right)$ \\
\hline 230.9 & 837.0 \\
153.9 & 837.0 \\
76.9 & 837.0 \\
0 & 837.0 \\
230.9 & 682.0 \\
153.9 & 682.0 \\
76.9 & 682.0 \\
0 & 682.0 \\
230.9 & 496.0 \\
153.9 & 496.0 \\
76.9 & 496.0 \\
0 & 496.0 \\
230.9 & 341.0 \\
153.9 & 341.0 \\
76.9 & 341.0 \\
0 & 341.0 \\
230.9 & 155.0 \\
153.9 & 155.0 \\
76.9 & 155.0 \\
0 & 155.0 \\
230.9 & 0 \\
153.9 & 0 \\
769 & 0 \\
0 & 0 \\
\hline
\end{tabular}

\section{Fuel CONSUMPTiON}

The literature provides different formulas for the consumption of an atmospheric gas burner for flame weeding. The factors taken into consideration for these algorithms generally include gas pressure, gas output section, and a specific constant that depends on the constructional characteristics of the burner itself (Hoffmann, 1990; de Rooy, 1992; Laguë et al., 1997). In the case of these burner prototypes, the specific constant is mainly determined by the structural characteristics of the external mixer. This parameter was not available for our burners, thus to find a function that could represent the LPG consumption we used a more general physics model.

The outflow of a liquefied gas under pressure within a container depends on the position of the exit hole (van den Bosch and Duijm, 2005). If the tank hole is located:

Table 3. Burner 3 combinations of the input sections of primary and secondary air.

\begin{tabular}{cc}
\hline \multicolumn{2}{c}{ of primary and secondary air. } \\
\hline Section Primary Air $\left(\mathrm{mm}^{2}\right)$ & Section Secondary Air $\left(\mathrm{mm}^{2}\right)$ \\
\hline 230.9 & 603.4 \\
153.9 & 603.4 \\
76.9 & 603.4 \\
0 & 603.4 \\
230.9 & 452.6 \\
153.9 & 452.6 \\
76.9 & 452.6 \\
0 & 452.6 \\
230.9 & 301.7 \\
153.9 & 301.7 \\
76.9 & 301.7 \\
0 & 301.7 \\
230.9 & 150.8 \\
153.9 & 150.8 \\
76.9 & 150.8 \\
0 & 150.8 \\
230.9 & 0 \\
153.9 & 0 \\
76.9 & 0 \\
0 & 0 \\
\hline
\end{tabular}

- high up, well above the level reached by the liquefied gas, the outflow is gaseous;

- close to the level reached by liquefied gas, the outflow is two-phase (liquid-gas);

- below the level reached by the liquefied gas, the outflow is liquid.

Considering the apparatus used during this experimental trial, we adopted the gaseous outflow model in order to explain the efflux of the gas from the nozzle of the external mixer. The mass flow rate for the gas outflow through an orifice, assuming an isentropic transformation, can be estimated by equation 2 (van den Bosch and Duijm, 2005):

$$
w=C_{d} \cdot A_{h} \cdot \sqrt{\frac{2}{\gamma-1}\left(\left(\frac{P_{a}}{P_{0}}\right)^{\left(\frac{2}{\gamma}\right)}-\left(\frac{P_{a}}{P_{0}}\right)^{\left(\frac{\gamma+1}{\gamma}\right)}\right) \cdot \rho_{0} \cdot P_{0} \cdot \gamma}
$$

where

$\mathrm{w}=$ mass flow rate $\left(\mathrm{kg} \mathrm{s}^{-1}\right)$,

$\mathrm{C}_{\mathrm{d}}=$ discharge coefficient (-),

$A_{h}=$ cross-sectional area hole (nozzle hole) $\left(\mathrm{m}^{2}\right)$,

$\mathrm{P}_{0}=$ initial gas pressure $(\mathrm{Pa})$,

$\mathrm{P}_{\mathrm{a}}=$ atmospheric pressure $(\mathrm{Pa})$,

$\rho_{0}=$ initial gas density $\left(\mathrm{kg} \mathrm{m}^{-3}\right)$,

$\gamma=$ heat capacity ratio (-).

A value of $\gamma$ equal to 1.51 was calculated according to the composition of the LPG used.

The density $\rho_{0}$ can be expressed by the equation of state of a real gas in the following way (eq. 3) (van den Bosch and Duijm, 2005):

$$
\begin{gathered}
P \cdot V=z \cdot n \cdot R \cdot T \\
\rho_{0}=\frac{1}{V}=\frac{P M}{z R T}
\end{gathered}
$$

where

$\mathrm{P}=$ gas pressure $(\mathrm{Pa})$,

$\mathrm{V}=$ volume $\left(\mathrm{m}^{3}\right)$,

$\mathrm{z}=$ compressibility factor $(-)$,

$\mathrm{n}=$ number of moles $(-)$,

$\mathrm{R}=$ gas constant $\left(\mathrm{J} \mathrm{kmol}^{-1} \mathrm{~K}^{-1}\right)$,

$\mathrm{T}=$ temperature $(\mathrm{K})$,

$\rho_{0}=$ gas density $\left(\mathrm{kg} \mathrm{m}^{-3}\right)$,

$\mathrm{v}=$ specific volume $\left(\mathrm{m}^{3} \mathrm{~kg}^{-1}\right)$,

$\mathrm{M}=$ molar mass $\left(\mathrm{kg} \mathrm{kmol}^{-1}\right)$.

A value of $\mathrm{R}$ equal to $8314 \mathrm{~J} \mathrm{kmol}^{-1} \mathrm{~K}^{-1}$ and a value of $\mathrm{M}$ equal to $51.1 \mathrm{~kg} \mathrm{kmol}^{-1}$ were calculated according to the composition of the LPG used.

Substituting $\rho_{0}$ in equation 2 , and assuming $\mathrm{P}$ in equation 4 equals $\mathrm{P}_{0}$, equation 5 is obtained:

$$
w=C_{d} \cdot A_{h} \cdot P_{0} \cdot \sqrt{\frac{M}{z R T} \cdot \gamma \cdot \frac{2}{\gamma-1}\left(\left(\frac{P_{a}}{P_{0}}\right)^{\left(\frac{2}{\gamma}\right)}-\left(\frac{P_{a}}{P_{0}}\right)^{\left(\frac{\gamma+1}{\gamma}\right)}\right)}
$$

This model is valid up to certain values of initial gas pressure $\mathrm{P}_{0}$. When the initial gas pressure increases and reaches a certain value, the gas outflow becomes sonic 
(critical outflow), and the mass flow rate becomes independent of the pressure after the hole (van den Bosch and Duijm, 2005).

The mass flow rate for sonic gas outflow follows equation 6 (van den Bosch and Duijm, 2005):

$$
w=C_{d} \cdot A_{h} \cdot \sqrt{\rho_{0} \cdot P_{0} \cdot \gamma \cdot\left(\frac{2}{\gamma+1}\right)^{\left(\frac{\gamma+1}{\gamma-1}\right)}}
$$

Substituting $\rho_{0}$ in equation 6 , and assuming $\mathrm{P}$ in equation 4 equals $\mathrm{P}_{0}$, equation 7 is obtained (van den Bosch and Duijm, 2005):

$$
w=C_{d} \cdot A_{h} \cdot P_{0} \cdot \sqrt{\frac{M}{z R T} \cdot \gamma \cdot\left(\frac{2}{\gamma+1}\right)^{\left(\frac{\gamma+1}{\gamma-1}\right)}}
$$

The sonic outflow (critical outflow) occurs when (eq. 7) (van den Bosch and Duijm, 2005):

$$
\begin{gathered}
\frac{P_{0}}{P_{a}} \geq\left(\frac{\gamma+1}{2}\right)\left(\frac{\gamma}{\gamma-1}\right) \\
P_{0} \geq P_{a} \cdot\left(\frac{\gamma+1}{2}\right)\left(\frac{\gamma}{\gamma-1}\right)
\end{gathered}
$$

In the equations above, the only construction characteristics of the burners are $A_{h}$ and $C_{d}$. The area $A_{h}$ is the section of the hole of the nozzle $\left(\mathrm{m}^{2}\right)$ and $\mathrm{C}_{\mathrm{d}}(-)$ is derived from the characteristics of the nozzle. This means that the LPG hourly consumption of the burners used in this trial depends on the nozzle of the external mixer and on the working pressure of the gas.

In the experiment, the LPG consumption was determined using burner 1 without the apparatus to vary the secondary area and with the external mixer with six side holes with a diameter of $7 \mathrm{~mm}$. Using the pressure regulator with a manometer, 10 different pressures in combination with three nozzles with hole diameter of 0.7 , 0.8 , and $0.9 \mathrm{~mm}$ were set. The pressure ranged from 0.05 to $0.5 \mathrm{MPa}$ in steps of $0.05 \mathrm{MPa}$. The atmospheric pressure was considered as $0.101 \mathrm{MPa}$. For each combination of pressure and nozzle section values, the hourly consumption was determined by weighing the LPG tank before and after one hour of burner working.

The data were then subjected to non-linear regression using the two outflow models described. The regression was performed using the model of gaseous outflow for values of absolute pressure lower than $0.201 \mathrm{MPa}$ (relative pressure $0.1 \mathrm{MPa}$ ), and using the model of sonic outflow for values of absolute pressure greater than or equal to $0.201 \mathrm{MPa}$. The limit value of absolute pressure (0.201 MPa) was identified according to the equation 9 .

The compressibility factor (z) varies with the gas pressure and temperature values (Rojey et al., 1997; van den Bosch and Duijm, 2005). In order not to overcomplicate the model or the subsequent statistical analysis, this parameter was considered constant by adopting an average value of 0.916 calculated from the data in table 4 , derived by interpolation from the general diagram for the coefficient $\mathrm{z}$ of real gases (Rojey et al., 1997).

Non-linear regression analysis statistically verifies whether the consumption data collected follows the physical model of chosen outflow and is able to determine the value of the discharge coefficient $\left(\mathrm{C}_{\mathrm{d}}\right)$ of the nozzles used. The discharge coefficient is a dimensionless value ranging from 0 to 1 . It is influenced by the friction and contraction coefficients, and depends on the geometrical and constructive characteristics of the nozzle.

The non-linear regression was performed with GraphPad Version 5.0, (Graphpad Software Motulsky, 2007) adopting different models to different portions of the data using the IF function of the software (Motulsky, 1999). More specifically, the LPG consumption data were regressed by adopting the subsonic gas out flow model (eq. 5) if values of $\mathrm{P}_{0}$ were lower than the value calculated from the equation 9. If the values of $\mathrm{P}_{0}$ were higher than the value calculated from equation 9, regressions of the LPG consumption data were performed assuming the sonic out flow model (eq. 7).

\section{RESULTS}

\section{DETERMINATION OF THE BEST RATIO BETWEEN THE SeCtions of The Primary and The SeCONdARY AIR}

With the experimental apparatus used we were not able to measure the flame length for some combinations of the inlet sections of primary and secondary air (fig. 6). In fact, for the lowest values of input sections of primary and secondary air, bright, yellow, and fringed flames were obtained, characterized by relatively lower temperatures than those recorded for the combinations which ensured a greater intake of air.

\section{Flame Temperature}

The temperature values recorded for the different combinations of primary and secondary air section of the three burners are shown in figures 7, 8, and 9, respectively.

A preliminary observation of the flame temperature data for the three burners reveals "regions" delimited by a range of combinations of values of primary and secondary air section, which seem to be associated with higher temperatures. Regarding burner 1 (fig. 7), the higher values of flame temperature were recorded for the combinations of the values of primary air section ranging from 76.9 to

Table 4. Values of the compressibility factor derived from the general diagram for a real gas at a temperature of $25^{\circ} \mathrm{C}$.

\begin{tabular}{cc} 
Absolute Pressure $(\mathrm{Pa})$ & Compressibility Factor z (-) \\
\hline 151325 & 0.966 \\
201325 & 0.950 \\
251325 & 0.937 \\
301325 & 0.936 \\
351325 & 0.924 \\
401325 & 0.916 \\
451325 & 0.896 \\
501325 & 0.885 \\
551325 & 0.879 \\
601325 & 0.871 \\
\hline
\end{tabular}




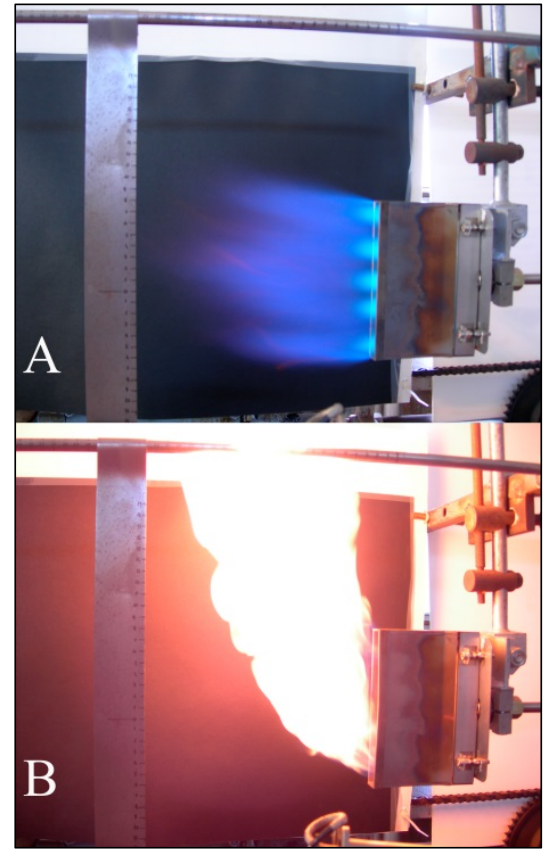

Figure 6. Types of flame obtained with the different combinations of the input section of primary and secondary air, in some cases we were not able to measure the flame length value: (A) measurable flame, (B) unmeasurable flame.

$230.9 \mathrm{~mm}^{2}$, and values of secondary air ranging from 682 and $837 \mathrm{~mm}^{2}$. For burner 2 (fig. 8), higher values of flame temperatures were recorded with the combinations of values of primary air higher than $76.9 \mathrm{~mm}^{2}$ and values of secondary air higher than $341 \mathrm{~mm}^{2}$. Concerning burner 3 (fig. 9), the "region" of higher temperature is quite narrow, in fact, in this case the higher values of flame temperature were recorded for the maximum values of secondary air section $\left(603.4 \mathrm{~mm}^{2}\right)$ combined with values of primary air section higher than $76.9 \mathrm{~mm}^{2}$. Tables 5 and 6 show results of the multiple regression and the analysis of variance of the multiple regression for the flame temperature values recorded for the three burners.

The values of the coefficient of determination and the adjusted coefficient of determination suggest that the flame temperature data fit quite well in accordance with the paraboloid function adopted (eq. 1).

The small value of $\mathrm{P}(\mathrm{P}<0.0001)$ from the analysis of variance of the multiple regression of the flame temperatures of the three burners would seem to indicate that, in accordance with the function of the equation 1, there is an association between the independent variables and the dependent variable (figs. 10-12).

Table 7 reports the estimation of the constants and the coefficients of the independent variable of the multiple regression of flame temperature values for the three burners. The $\mathrm{P}$ value reported in table 7 is the probability of being wrong in concluding that the coefficient is not zero. Assuming a significance level value equal to $5 \%$, we can conclude that a coefficient is not zero when the $\mathrm{P}$ value is lower than 0.05 . If a coefficient is not different from zero $(\mathrm{P}>0.05)$, the associated independent variable does not affect the dependent variable.

Table 8 shows the combinations of the predicted values of secondary and primary air sections, which according to the adopted multiple regression model, give the highest values of temperature.

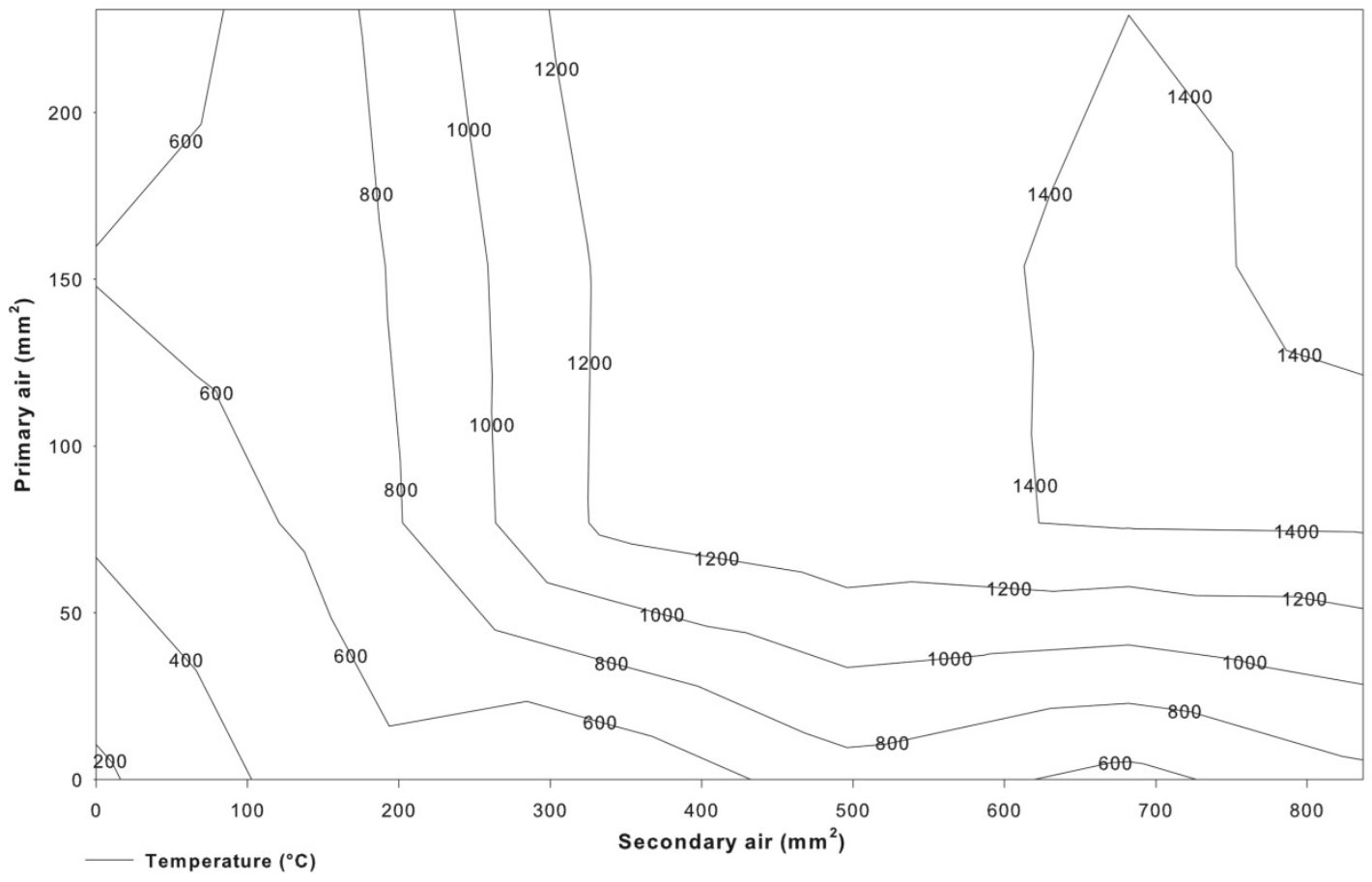

Figure 7. Burner 1: contour plot of the flame temperatures recorded for the different combinations of input sections of primary and secondary air. 


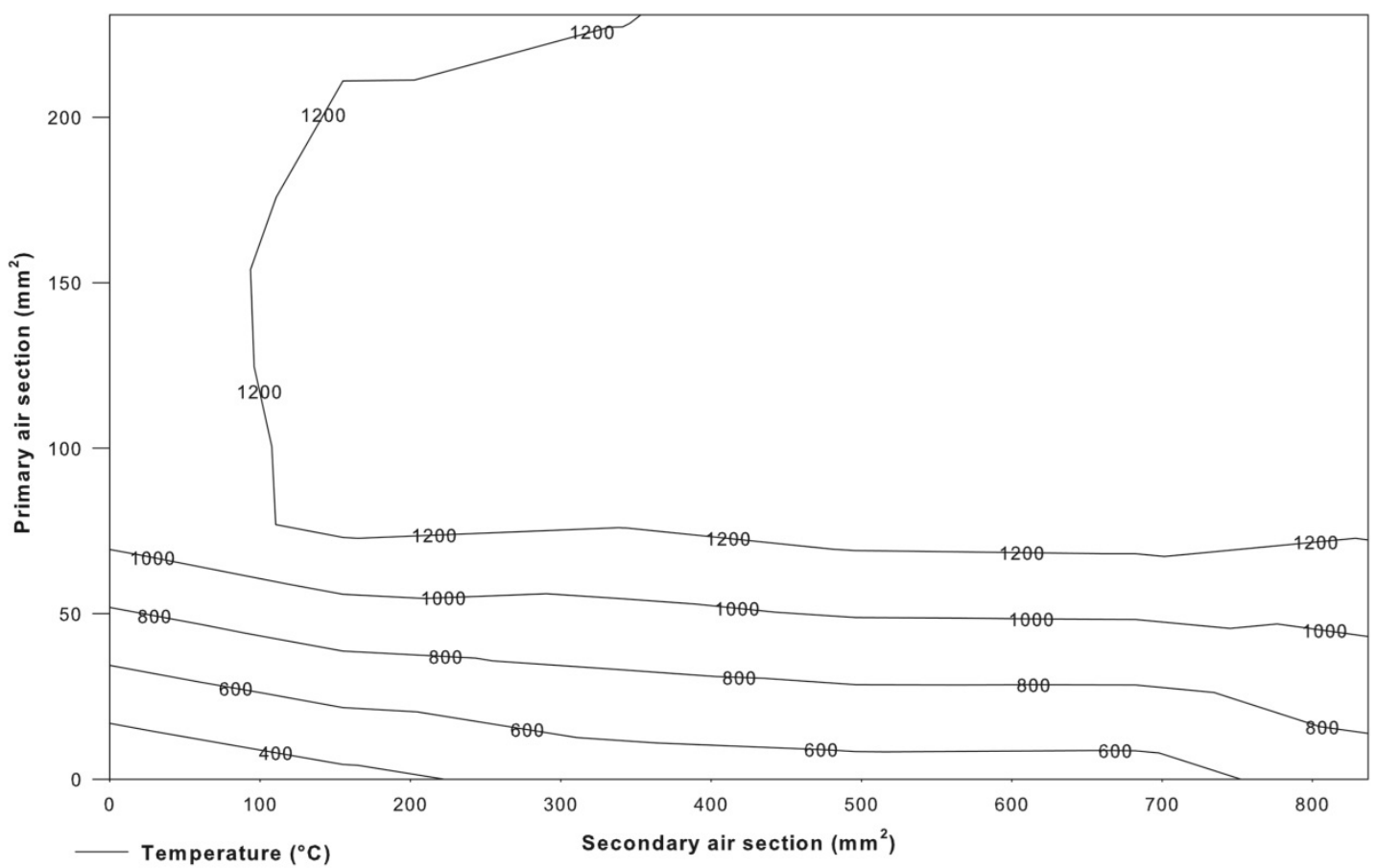

Figure 8. Burner 2: contour plot of the flame temperatures recorded for the different combinations of input sections of primary and secondary air.

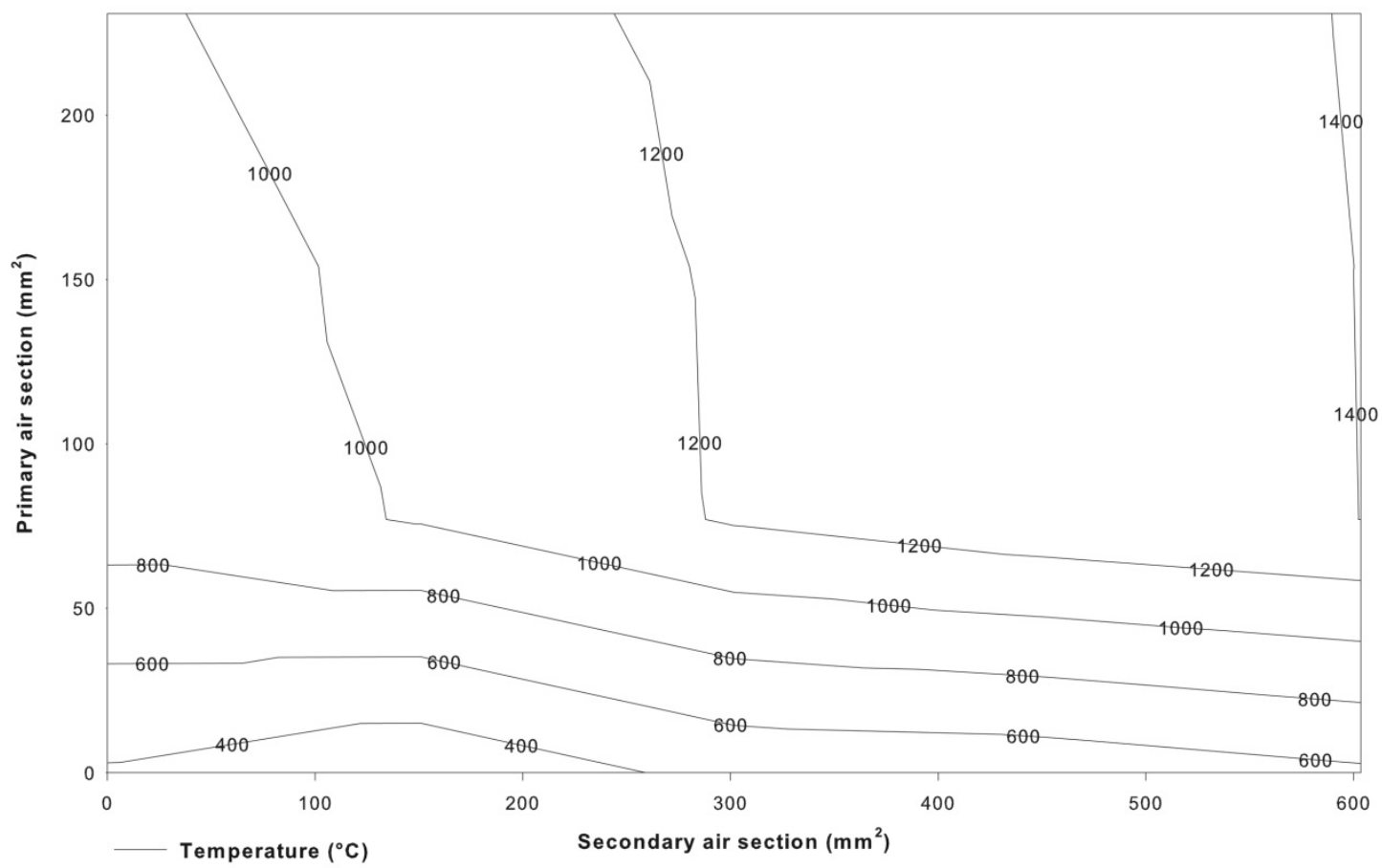

Figure 9. Burner 3: contour plot of the flame temperatures recorded for the different combinations of input sections of primary and secondary air.

Table 5. Values of multiple correlation coefficient $(R)$, coefficient of determination $\left(R^{2}\right)$, adjusted coefficient of determination (Adj. $\left.\mathbf{R}^{2}\right)$, and standard error of the estimate, calculated for the values of flame temperature of the three burners.

\begin{tabular}{ccccc}
\hline Burner & $\mathrm{R}$ & $\mathrm{R}^{2}$ & Adj. $\mathrm{R}^{2}$ & Standard Error \\
\hline 1 & 0.9540 & 0.9101 & 0.8852 & 146.0269 \\
2 & 0.9630 & 0.9274 & 0.9072 & 107.1965 \\
3 & 0.9619 & 0.9253 & 0.8986 & 119.7001 \\
\hline
\end{tabular}

Table 9 shows the difference of the maximum predicted values of flame temperature, and the confidence interval of the overlap test of the three burners tested in the experimental trial.

If the range between the lower and upper limits of the $95 \%$ confidence interval contains zero, then the null 
Table 6. Results of the analysis of variance of the multiple regression of the flame temperature values recorded for the three burners.

\begin{tabular}{|c|c|c|c|c|c|c|}
\hline Burner & & $\begin{array}{c}\text { Degree of } \\
\text { Freedom }\end{array}$ & Sum of Squares & Mean Square & $\mathrm{F}$ & $\mathrm{P}$ \\
\hline \multirow{3}{*}{1} & Regression & 5 & 3887020.5 & 777404.1 & 36.46 & $<0.0001$ \\
\hline & Residual & 18 & 383829.5 & 21323.9 & & \\
\hline & Total & 23 & 4270850.1 & 185689.1 & & \\
\hline \multirow{3}{*}{2} & Regression & 5 & 2641344.2 & 528268.8 & 45.97 & $<0.0001$ \\
\hline & Residual & 18 & 206839.8 & 11491.1 & & \\
\hline & Total & 23 & 2848184.0 & 123834.1 & & \\
\hline \multirow{3}{*}{3} & Regression & 5 & 2484027.7 & 496805.5 & 34.67 & $<0.0001$ \\
\hline & Residual & 14 & 200593.7 & 14328.1 & & \\
\hline & Total & 19 & 2684621.4 & 141295.9 & & \\
\hline
\end{tabular}

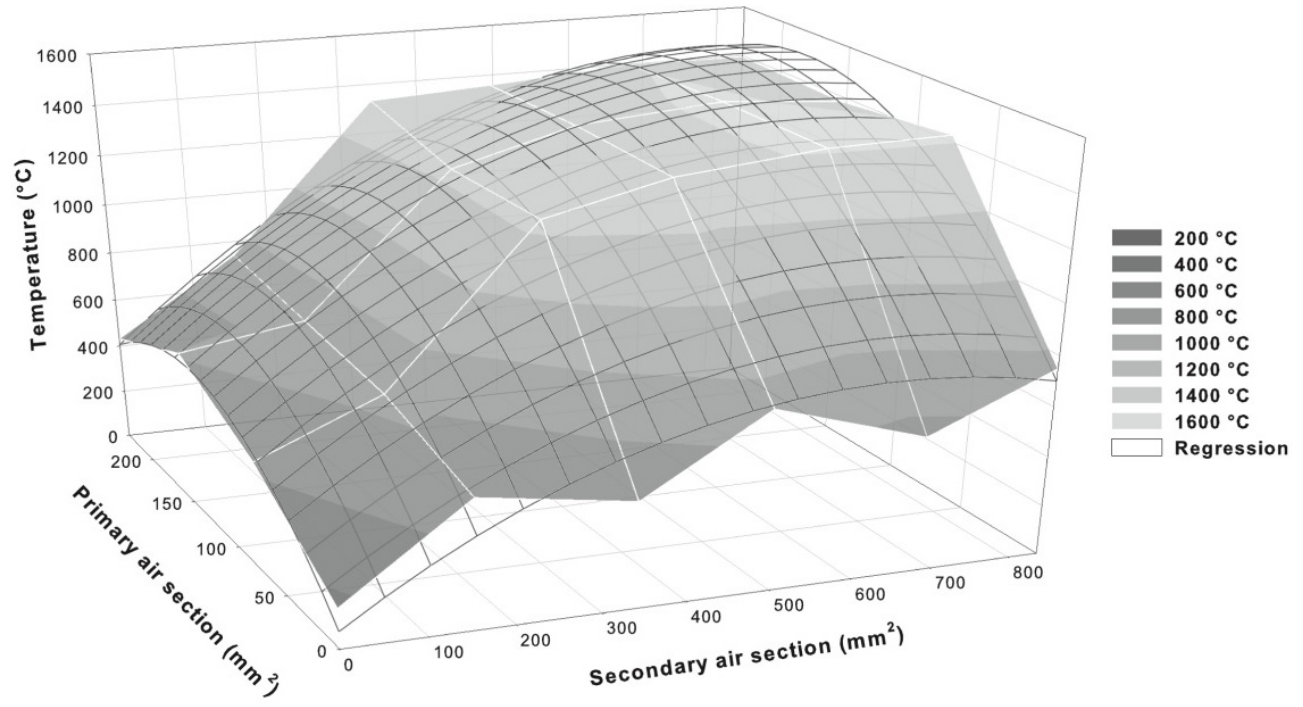

Figure 10. Burner 1: mesh plot and multiple regressions of the flame temperatures values recorded for the different combinations of input sections of primary and secondary air.

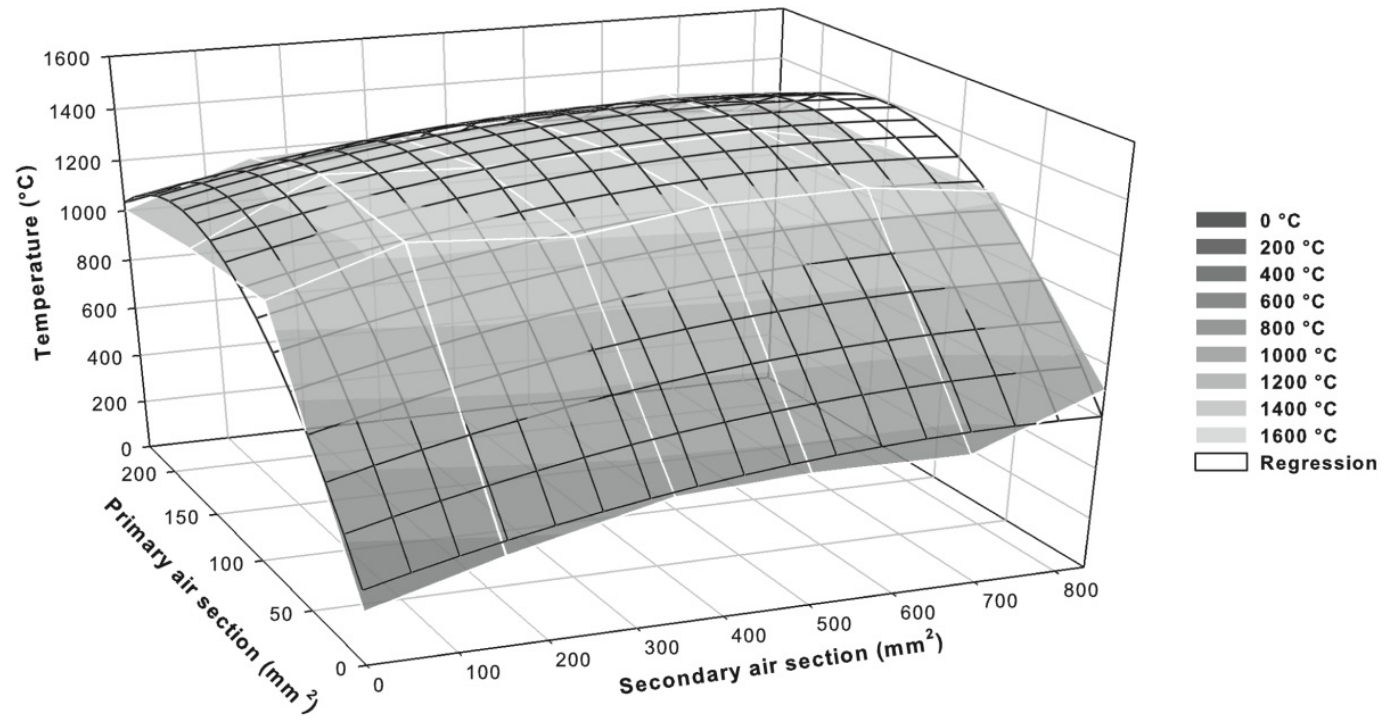

Figure 11. Burner 2: mesh plot and multiple regressions of the flame temperatures values recorded for the different combinations of input sections of primary and secondary air.

hypothesis that the maximum predicted values of the flame temperature are the same cannot be rejected.

\section{Flame Length}

Our experimental apparatus did not enable us to determine the flame length for some combinations of the primary and secondary air sections (fig. 6). The statistical analysis thus only included the combinations of secondary and primary air that resulted in a stable and measurable flame.

The values of flame length recorded for the different combinations of the primary and secondary air sections of 


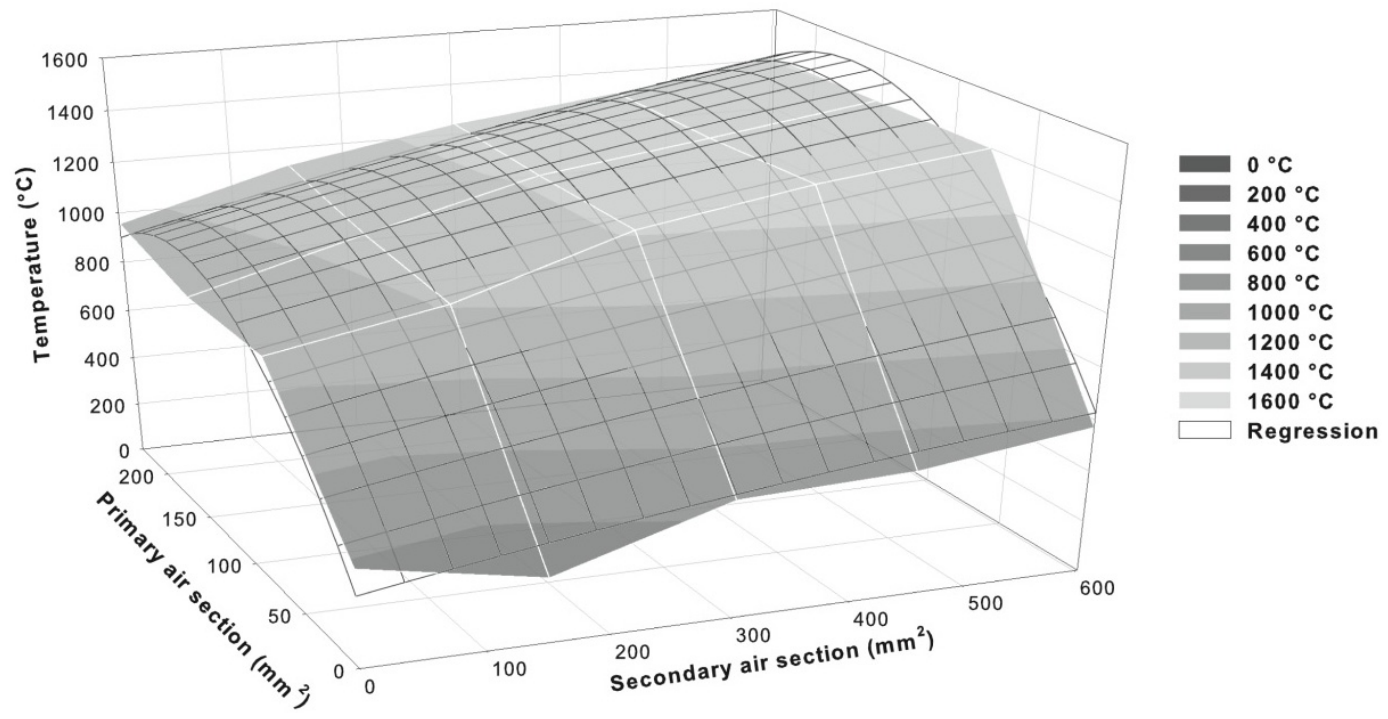

Figure 12. Burner 3: mesh plot and multiple regressions of the flame temperatures values recorded for the different combinations of input sections of primary and secondary air.

Table 7. Estimation of the regression coefficients of flame temperature values according to the adopted paraboloid function (eq. 1).

\begin{tabular}{|c|c|c|c|c|c|c|c|}
\hline Burner & Coefficient & Estimated Value & $\mathrm{SE}^{[\mathrm{a}]}$ & $\mathrm{t}^{[\mathrm{b}]}$ & $\mathrm{P}^{[\mathrm{c}]}$ & LL $95 \% \mathrm{CI}^{[\mathrm{d}]}$ & UL $95 \% \mathrm{CI}^{[\mathrm{e}]}$ \\
\hline \multirow{6}{*}{1} & $z_{0}$ & 70.4951 & 100.6228 & 0.7006 & 0.4925 & -140.9056 & 281.8958 \\
\hline & $a$ & 2.2048 & 0.3971 & 5.5524 & $<0.0001$ & 1.3705 & 3.0390 \\
\hline & $b$ & 7.1122 & 1.3120 & 5.4209 & $<0.0001$ & 4.3558 & 9.8686 \\
\hline & $c$ & -0.0017 & 0.0004 & -4.0568 & 0.0007 & -0.0026 & -0.0008 \\
\hline & $d$ & -0.0245 & 0.0050 & -4.8673 & 0.0001 & -0.0351 & -0.0139 \\
\hline & $e$ & 0.0021 & 0.0012 & 1.7570 & 0.0959 & -0.0004 & 0.0046 \\
\hline \multirow{6}{*}{2} & $z_{0}$ & 290.0173 & 73.8660 & 3.9263 & 0.0010 & 134.8307 & 445.2039 \\
\hline & $a$ & 0.8411 & 0.2915 & 2.8854 & 0.0099 & 0.2287 & 1.4535 \\
\hline & $b$ & 11.0925 & 0.9631 & 11.5172 & $<0.0001$ & 9.0691 & 13.1160 \\
\hline & $c$ & -0.0006 & 0.0003 & -1.7791 & 0.0921 & -0.0012 & 0.0001 \\
\hline & $d$ & -0.0341 & 0.0037 & -9.2309 & $<0.0001$ & -0.0419 & -0.0263 \\
\hline & $e$ & -0.0008 & 0.0009 & -0.9561 & 0.3517 & -0.0027 & 0.0010 \\
\hline \multirow{6}{*}{3} & $\overline{z_{0}}$ & 278.8319 & 88.0775 & 3.1658 & 0.0069 & 89.9244 & 467.7394 \\
\hline & $a$ & 0.7638 & 0.4732 & 1.6141 & 0.1288 & -0.2511 & 1.7788 \\
\hline & $b$ & 9.5654 & 1.1741 & 8.1468 & $<0.0001$ & 7.0471 & 12.0836 \\
\hline & $c$ & -0.0003 & 0.0007 & -0.4399 & 0.6668 & -0.0018 & 0.0012 \\
\hline & $d$ & -0.0298 & 0.0045 & -6.5899 & $<0.0001$ & -0.0395 & -0.0201 \\
\hline & $e$ & 0.0012 & 0.0015 & 0.8274 & 0.4219 & -0.0019 & 0.0043 \\
\hline
\end{tabular}

[a] SE is standard error.

[b] $t$ is t-statistic.

[c] $\mathrm{P}$ is $\mathrm{p}$-value based on $\mathrm{t}$.

[d] LL 95\%CI is lower limit of the $95 \%$ confidence interval.

[e] UL $95 \% \mathrm{CI}$ is upper limit of the $95 \%$ confidence interval.

the three burners are shown in figures, 13, 14, and 15, respectively.

The contour plots of flame length values of the three burners highlight some "regions" delimited by combinations of primary and secondary air section, which seem to be associated with the higher values of flame length. The highest values of flame length of burner 1 (fig. 13) are included in the region around the value of primary air section of $154 \mathrm{~mm}^{2}$ and values of secondary air section

Table 8. Maximum predicted values of flame temperature and relative values of the independent variables according to the multiple regression function adopted (eq. 1).

\begin{tabular}{ccccc}
\multicolumn{5}{c}{ regression function adopted (eq. 1). } \\
\hline Burner & $\begin{array}{c}\text { Secondary Air } \\
\text { Section } \\
\left(\mathrm{mm}^{2}\right)\end{array}$ & $\begin{array}{c}\text { Primary Air } \\
\text { Section } \\
\left(\mathrm{mm}^{2}\right)\end{array}$ & $\begin{array}{c}\text { Temperature } \\
\left({ }^{\circ} \mathrm{C}\right)\end{array}$ & $\begin{array}{c}\text { Standard } \\
\text { Error }\end{array}$ \\
\hline 1 & 732.38 & 173.18 & 1519.8 & 146.03 \\
2 & 627.75 & 158.75 & 1416.0 & 107.20 \\
3 & 603.44 & 173.18 & 1516.8 & 119.70 \\
\hline
\end{tabular}

lower than $341 \mathrm{~mm}^{2}$. Regarding burner 2 (fig. 14), the highest values of flame length were recorded for values of secondary air section lower than $341 \mathrm{~mm}^{2}$ and values of primary air section lower than $154 \mathrm{~mm}^{2}$. Concerning burner 3 (fig. 15), the highest values of flame length seem

Table 9. Difference of the maximum predicted values of flame temperature and $95 \%$ confidence interval of the overlap test.

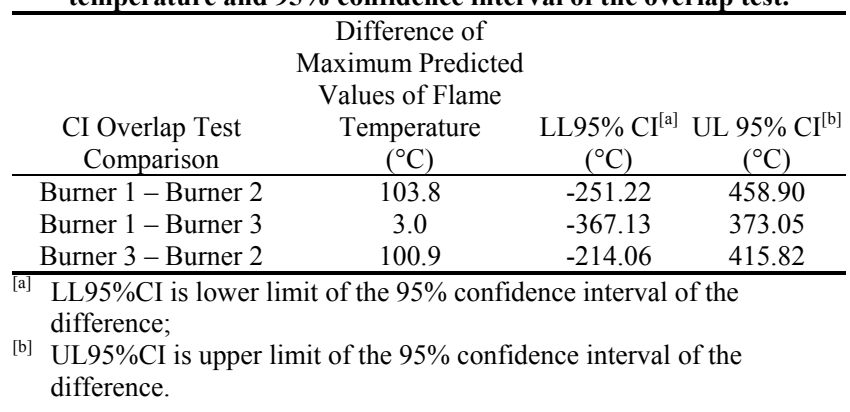




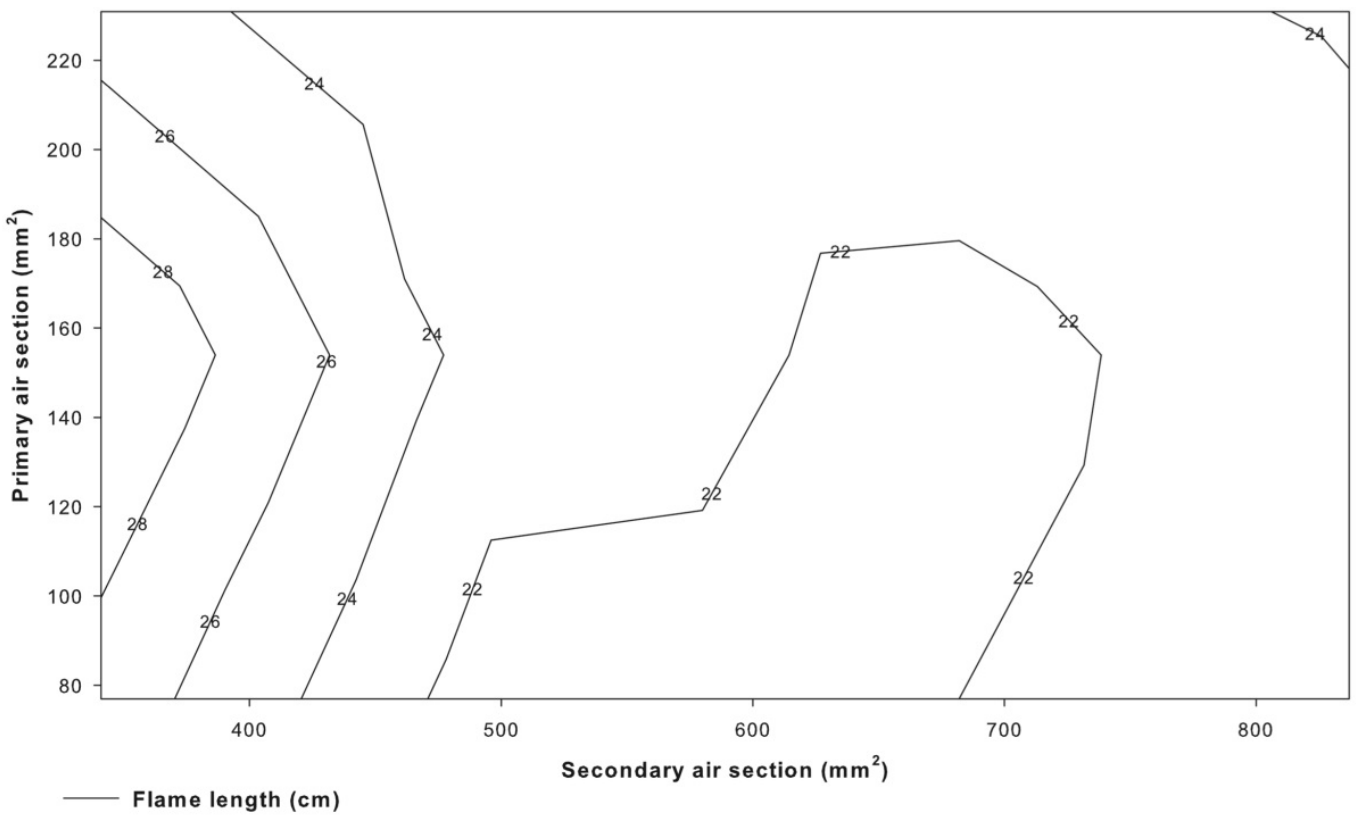

Figure 13. Burner 1: contour plot of the values of flame length recorded for the different combinations of input sections of primary and secondary air.

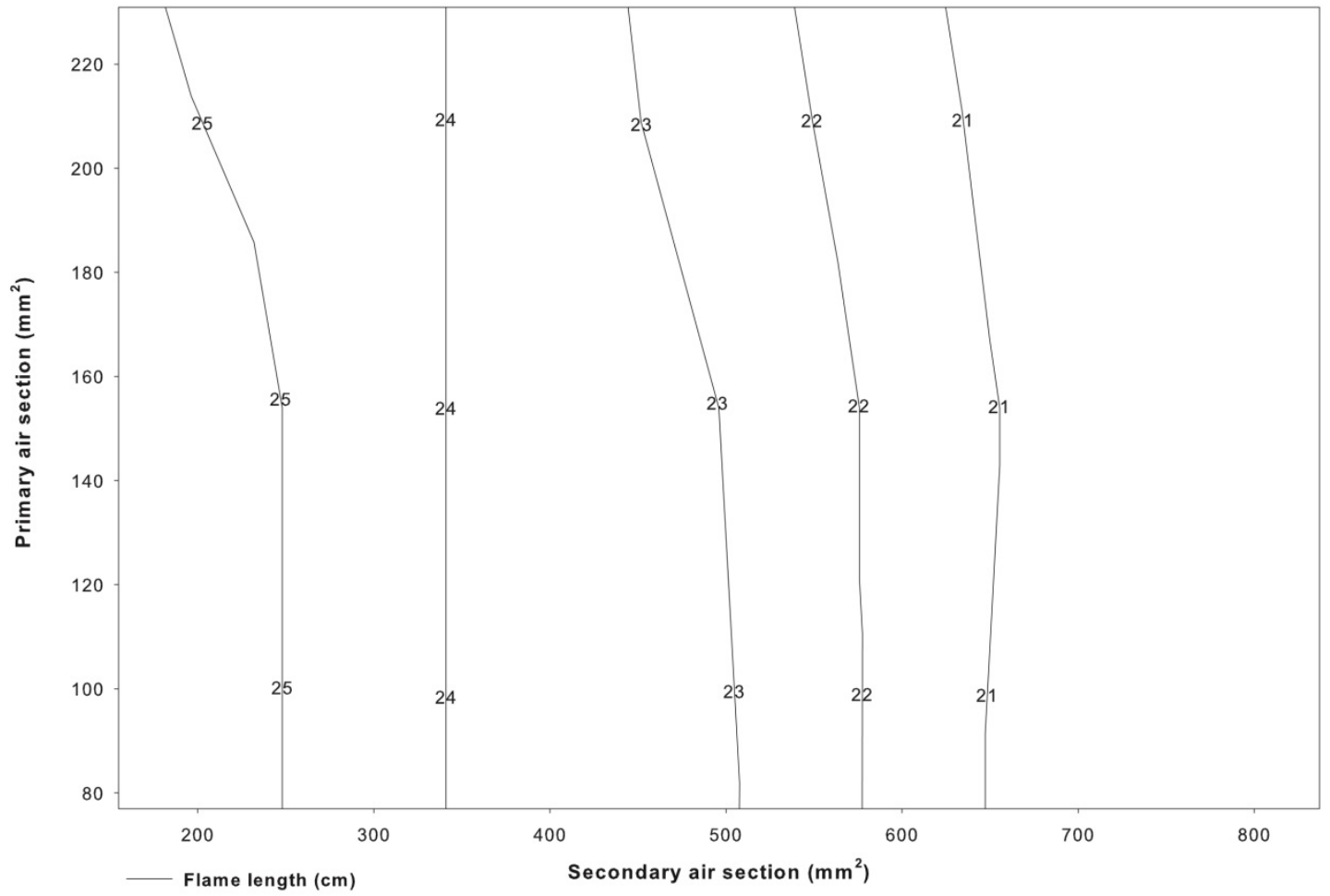

Figure 14. Burner 2: contour plot of the values of flame length recorded for the different combinations of input sections of primary and secondary air.

to be associated with values of secondary air section higher than $453 \mathrm{~mm}^{2}$. Tables 10 and 11 report the results of the multiple regression and the analysis of variance of the multiple regression for the flame length values recorded for the three burners.

The values of the coefficient of determination and the adjusted coefficient of determination of burners 2 and 3 suggest that the data of the flame length fit quite well in accordance with the paraboloid function adopted (eq. 1).
The values of coefficient of determination and the adjusted coefficient of determination obtained for burner 1 are lower than 0.8 .

Assuming a significance level of $5 \%(\mathrm{P}<0.05)$ from the results of the analysis of variance of the multiple regression of the flame length data of the three burners, we can conclude that, according to the adopted function (eq. 1), the independent variables can be used to predict the dependent variable (figs. 16-18). 


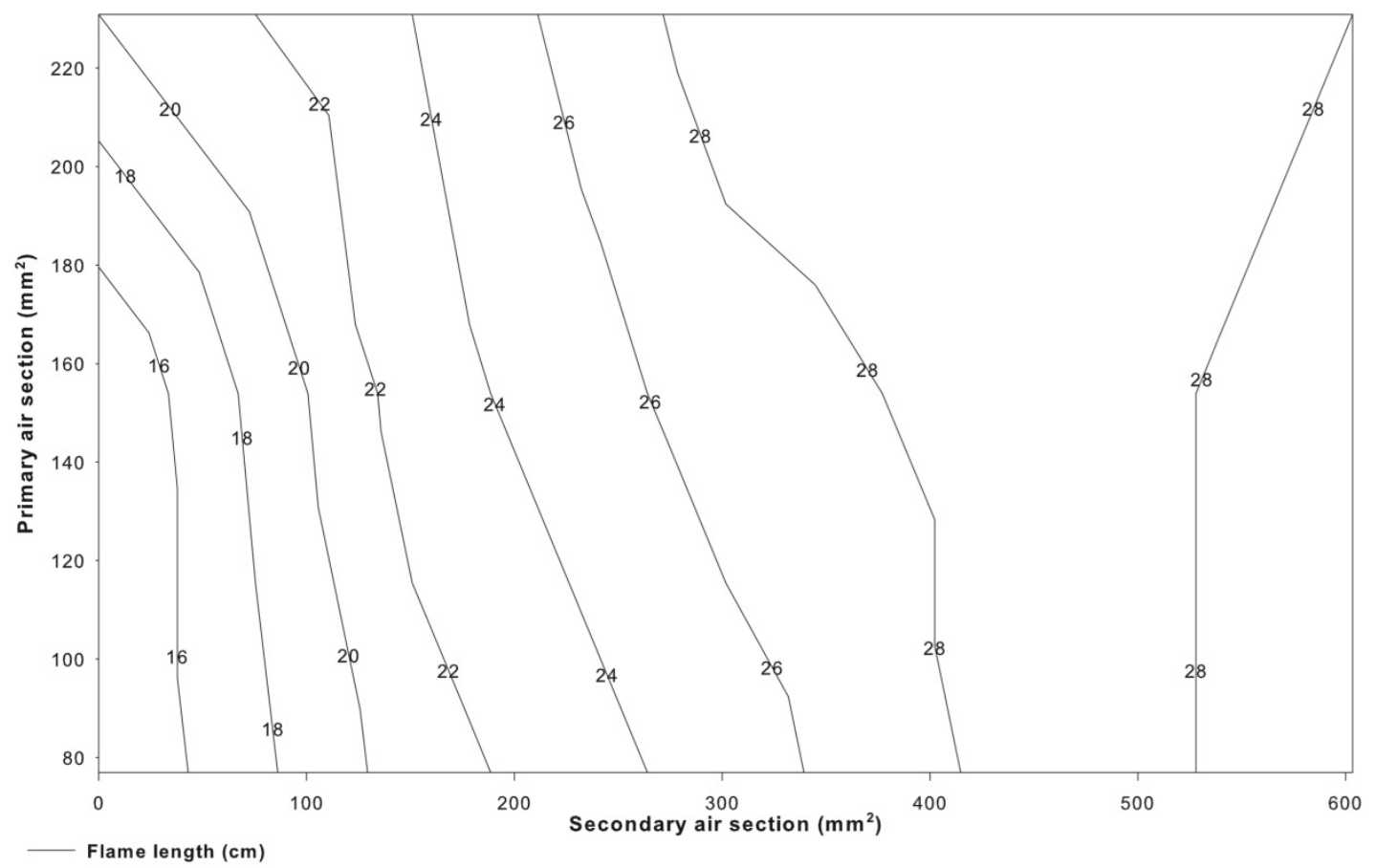

Figure 15. Burner 3: contour plot of the values of flame length recorded for the different combinations of input sections of primary and secondary air.

Table 10. Values of multiple correlation coefficient $(R)$, coefficient of determination $\left(\mathbf{R}^{2}\right)$, adjusted coefficient of determination (Adj. $\mathbf{R}^{2}$ ), and standard error of the estimated calculated for the values of flame length of the three burners.

\begin{tabular}{ccccc}
\hline Burner & $\mathrm{R}$ & $\mathrm{R}^{2}$ & Adj. $\mathrm{R}^{2}$ & Standard Error \\
\hline 1 & 0.8903 & 0.7927 & 0.6199 & 1.6076 \\
2 & 0.9802 & 0.9608 & 0.9391 & 0.5150 \\
3 & 0.9891 & 0.9784 & 0.9663 & 0.9529 \\
\hline
\end{tabular}

Table 11. Results of the analysis of variance of the multiple regression of the values of flame length recorded for the three burners.

\begin{tabular}{ccccccc}
\hline \multirow{2}{*}{ Burner } & & $\begin{array}{c}\text { Degree of } \\
\text { Freedom }\end{array}$ & $\begin{array}{c}\text { Sum of } \\
\text { Square }\end{array}$ & $\begin{array}{c}\text { Mean } \\
\text { Square }\end{array}$ & F & P \\
\hline \multirow{2}{*}{1} & Regression & 5 & 59.29 & 11.86 & 4.59 & 0.0454 \\
& Residual & 6 & 15.51 & 2.58 & & \\
& Total & 11 & 74.80 & 6.80 & & \\
\hline \multirow{2}{*}{2} & Regression & 5 & 58.55 & 11.71 & 44.16 & $<0.0001$ \\
& Residual & 9 & 2.39 & 0.27 & & \\
& Total & 14 & 60.94 & 4.35 & & \\
\hline \multirow{2}{*}{3} & Regression & 5 & 369.56 & 73.91 & 81.41 & $<0.0001$ \\
& Residual & 9 & 8.17 & 0.91 & & \\
& Total & 14 & 377.73 & 26.98 & & \\
\hline
\end{tabular}

Table 12 shows estimates of the constants and the coefficients of the independent variable of the regression of flame length values for the three burners.

If a $\mathrm{P}$ value reported in table 12 for the coefficients of the second order surface (eq. 1) is greater than 0.05 , we can conclude, assuming a significance level of $5 \%$, that the associated variable does not affect the dependent variable. Table 13 shows the combinations of the predicted values of the secondary and primary air section, that according to the adopted multiple regression model, enable obtaining the highest values of flame length.

Table 14 reports the difference of the maximum predicted values of flame length, and the confidence interval of the overlap test of the three burners tested in the experimental trial. Only the range between the lower and upper limits of the $95 \%$ confidence interval of the difference in the maximum predicted values of burners 2 and 3 does not contain zero. In this case, assuming a significance level of $5 \%$, we can conclude that these two values of flame length are statistically different.

\section{Fuel CONSUMPTION}

Figure 19 and tables 15 and 16 report the results of the nonlinear regression analysis on the values of the LPG consumption, recorded for the different working pressures and with three different nozzle hole diameters, according to the mixed gaseous outflow model (subsonic/sonic). Non-linear regression for the three nozzles provided $\mathrm{R}^{2}$ values very close to 1 for the goodness of fit of the LPG consumption to the adopted outflow model (Motulsky, 2007).

The term "run" means a series of consecutive points lying either above or below the curve. The "runs" test was performed to verify that the curves identified for the three nozzles had no systematic deviations from the consumption data collected. In all three cases, the analysis showed P values greater than 0.05 (table 16).

If $N_{a}$ is the number of points above the curve and $N_{b}$ is the number of points below the curve, the number of "runs" expected is given by:

$$
\frac{2 N_{a} N_{b}}{N_{a}+N_{b}}+1
$$

If the number of "runs" is lower than expected, the model and the curve could deviate systematically from the data. If the runs test reports a $\mathrm{P}$ value close to 0 or below the level of significance chosen, it is possible to conclude that the experimental data observed do not really follow 


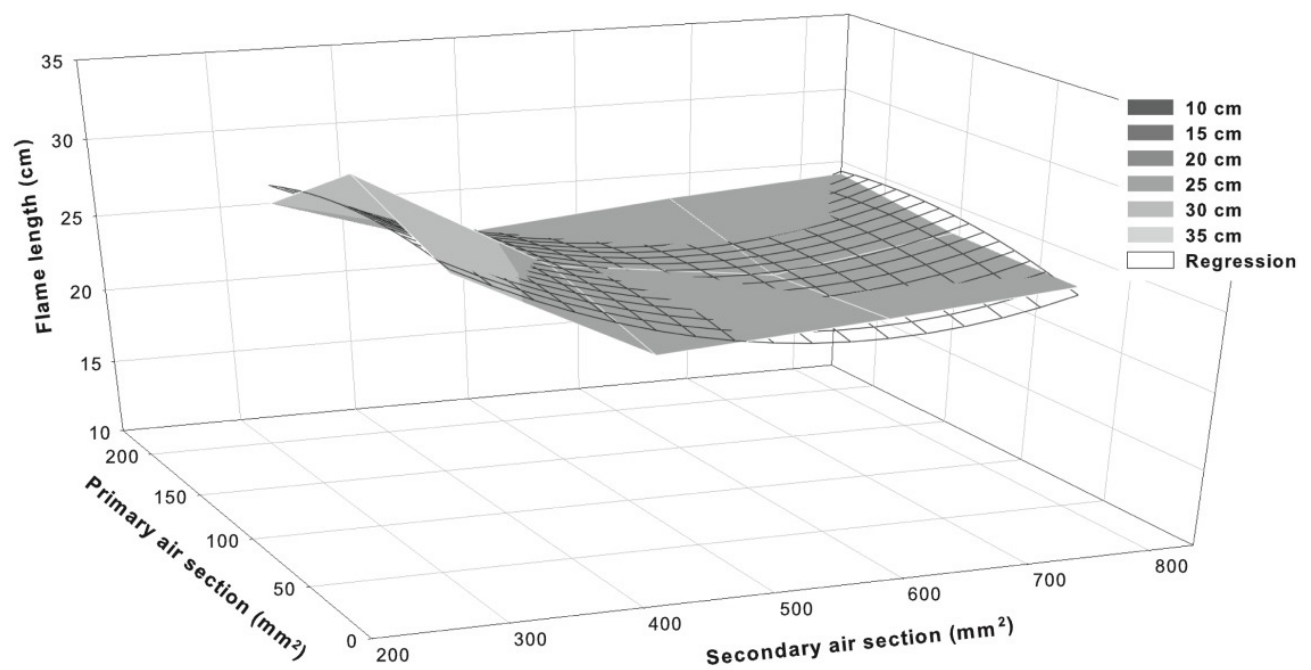

Figure 16. Burner 1: mesh plot and multiple regressions of the values of flame length recorded for the different combinations of input sections of primary and secondary air.

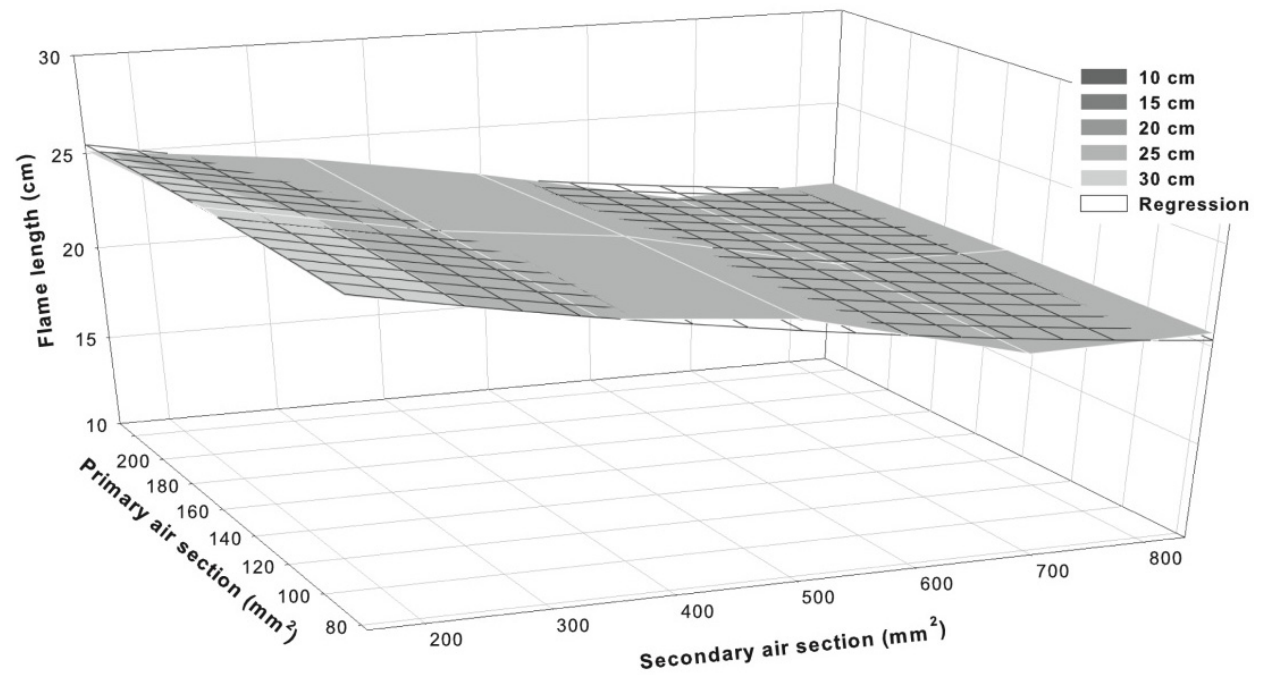

Figure 17. Burner 2: mesh plot and multiple regressions of the values of flame length recorded for the different combinations of input sections of primary and secondary air.

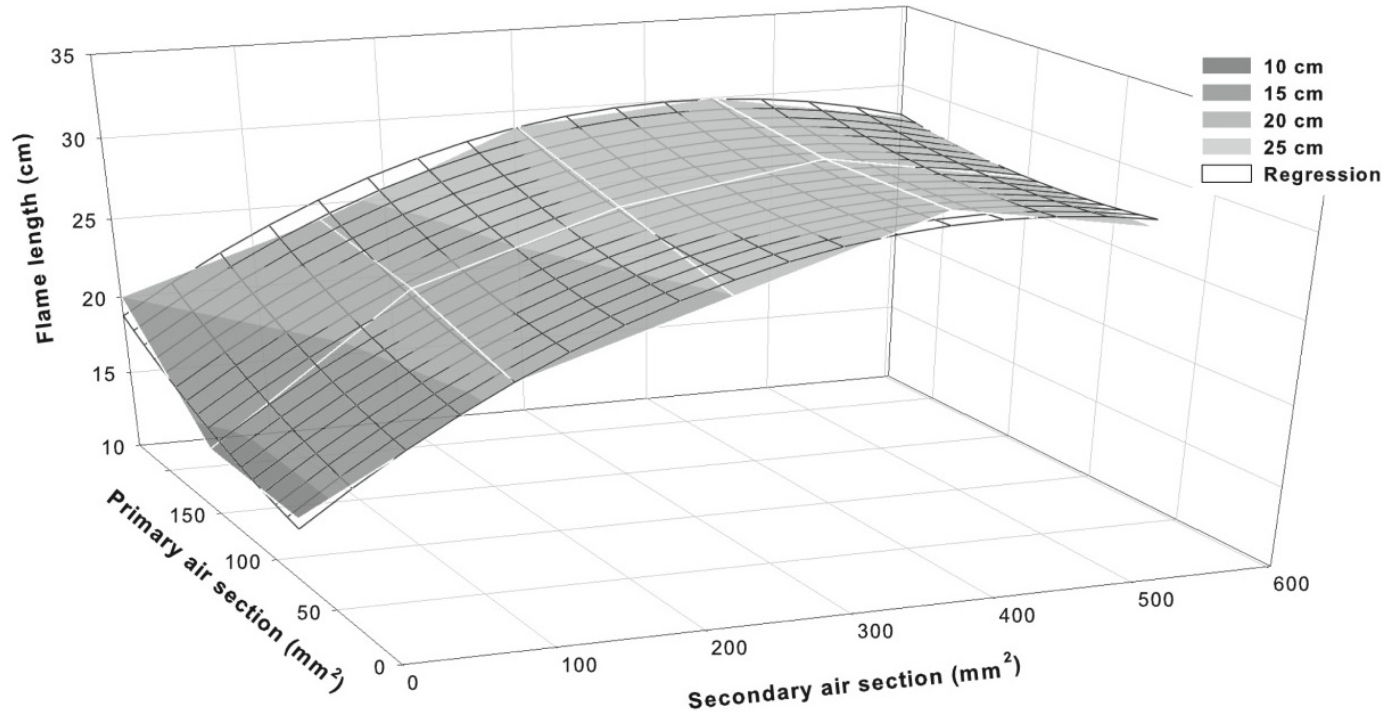

Figure 18. Burner 3: mesh plot and multiple regressions of the values of flame length recorded for the different combinations of input sections of primary and secondary air. 
Table 12. Estimates of the coefficients of the regression model (eq. 1) of flame length values.

\begin{tabular}{|c|c|c|c|c|c|c|c|}
\hline Burner & Coefficient & Estimated Value & $\mathrm{SE}^{[\mathrm{a}]}$ & $\mathrm{t}^{[\mathrm{b}]}$ & $\mathrm{P}^{[\mathrm{c}]}$ & LL $95 \% \mathrm{CI}^{[\mathrm{d}]}$ & $\mathrm{UL} 95 \% \mathrm{CI}^{[\mathrm{e}]}$ \\
\hline \multirow{6}{*}{1} & $z_{0}$ & 47.2308 & 7.6965 & 6.1366 & 0.0009 & 28.3981 & 66.0636 \\
\hline & $a$ & -0.0860 & 0.0221 & -3.8948 & 0.0080 & -0.1401 & -0.0320 \\
\hline & $b$ & 0.0286 & 0.0577 & 0.4955 & 0.6379 & -0.1126 & 0.1697 \\
\hline & $c$ & $6.2015 \times 10^{-5}$ & $1.7874 \times 10^{-5}$ & 3.4695 & 0.0133 & $1.827810^{-5}$ & 0.0001 \\
\hline & $d$ & -0.0002 & 0.0002 & -0.9564 & 0.3758 & -0.0006 & 0.0003 \\
\hline & $e$ & $3.9710 \times 10^{-5}$ & $4.0134 \times 10^{-5}$ & 0.9894 & 0.3607 & $-5.8497 \times 10^{-5}$ & 0.0001 \\
\hline \multirow{6}{*}{2} & $z_{0}$ & 27.8496 & 1.3459 & 20.6928 & $<0.0001$ & 24.8050 & 30.8941 \\
\hline & $a$ & -0.0137 & 0.0031 & -4.4355 & 0.0016 & -0.0207 & -0.0067 \\
\hline & $b$ & 0.0048 & 0.0155 & 0.3118 & 0.7623 & -0.0301 & 0.0398 \\
\hline & $c$ & $4.8951 \times 10^{-6}$ & $2.7305 \times 10^{-6}$ & 1.7927 & 0.1066 & $-1.2818 \times 10^{-6}$ & $1.1072 \times 10^{-5}$ \\
\hline & $d$ & $-3.0946 \times 10^{-5}$ & $4.7611 \times 10^{-5}$ & -0.6500 & 0.5319 & -0.0001 & $7.6758 \times 10^{-5}$ \\
\hline & $e$ & $4.6367 \times 10^{-6}$ & $8.7702 \times 10^{-6}$ & 0.5287 & 0.6098 & $-1.5203 \times 10^{-5}$ & $2.4476 \times 10^{-5}$ \\
\hline \multirow{6}{*}{3} & $z_{0}$ & 12.7714 & 2.0938 & 6.0996 & 0.0002 & 8.0349 & 17.5080 \\
\hline & $a$ & 0.0640 & 0.0050 & 12.9311 & $<0.0001$ & 0.0528 & 0.0752 \\
\hline & $b$ & -0.0013 & 0.0280 & -0.0465 & 0.9639 & -0.0645 & 0.0619 \\
\hline & $c$ & $-6.0679 \times 10^{-5}$ & $6.4604 \times 10^{-6}$ & -9.3924 & $<0.0001$ & $-7.5293 \times 10^{-5}$ & $-4.6064 \times 10^{-5}$ \\
\hline & $d$ & 0.0001 & $8.8096 \times 10^{-5}$ & 1.3412 & 0.2127 & $-8.1128 \times 10^{-5}$ & 0.0003 \\
\hline & $e$ & $-5.1673 \times 10^{-5}$ & $1.8350 \times 10^{-5}$ & -2.8160 & 0.0202 & $-9.3183 \times 10^{-5}$ & $-1.0163 \times 10^{-5}$ \\
\hline
\end{tabular}

SE is standard error.

[b] $t$ is t-statistic.

[c] $\mathrm{P}$ is $\mathrm{p}$-value based on $\mathrm{t}$.

[d] LL 95\%CI is lower limit of the 95\% confidence interval.

[e] UL $95 \% \mathrm{CI}$ is upper limit of the $95 \%$ confidence interval.

Table 13. Maximum predicted values of flame length and relative values of the independent variables according to the multiple regression function adopted (eq. 1).

\begin{tabular}{ccccc}
\hline & $\begin{array}{c}\text { Secondary } \\
\text { Air Section } \\
\left(\mathrm{mm}^{2}\right)\end{array}$ & $\begin{array}{c}\text { Primary } \\
\text { Air Section } \\
\left(\mathrm{mm}^{2}\right)\end{array}$ & $\begin{array}{c}\text { Flame } \\
\text { Length } \\
(\mathrm{cm})\end{array}$ & $\begin{array}{c}\text { Standard } \\
\text { Error }\end{array}$ \\
\hline 1 & 341.00 & 134.70 & 27.85 & 1.61 \\
2 & 155.00 & 86.59 & 26.09 & 0.52 \\
3 & 414.86 & 230.91 & 29.94 & 0.95 \\
\hline
\end{tabular}

Table 14. Difference of the maximum predicted values of flame length and $95 \%$ confidence interval of the overlap test. Difference of Maximum Predicted Values of

\begin{tabular}{cccc}
$\begin{array}{c}\text { CI Overlap Test } \\
\text { Comparison }\end{array}$ & $\begin{array}{c}\text { Flame Length } \\
(\mathrm{cm})\end{array}$ & $\begin{array}{c}\text { LL 95\% CI } \\
(\mathrm{cm})\end{array}$ & $\begin{array}{c}\text { UL 95\% CI } \\
(\mathrm{cm})\end{array}$ \\
\hline Burner 1 - Burner 2 & 1.76 & -1.59 & 5.11 \\
Burner 3 - Burner 1 & 2.09 & -1.61 & 5.79 \\
Burner 3 - Burner 2 & 3.85 & 1.73 & 5.97 \\
\hline
\end{tabular}

[a] LL95\%CI is lower limit of the $95 \%$ confidence interval of the difference;

[b] UL95\%CI is upper limit of the 95\% confidence interval of the difference.

the function of the model adopted (Motulsky and Christopoulos, 2003).

Table 18 reports the estimates of the discharge coefficients $\left(C_{d}\right)$ for the three nozzles calculated according to our gaseous outflow model. These values ranged from 0.91 to 0.93, with low standard error, and the limits of the $95 \%$ confidence interval are relatively close to the 0.91 to 0.93 range (Motulsky and Christopoulos, 2003). Table 18 shows the difference in the estimated values of the discharge coefficients, and the confidence interval of the overlap test of the three nozzles tested.

In all three comparisons, the range delimited by the upper and the lower limit of the $95 \%$ confidence interval of the difference in the estimated discharge coefficients contain the value of zero.

\section{DISCUSSION \\ RAtio BetWeen the Sections of The Primary AND THE SECONDARY AIR}

The results of the multiple regression analysis (tables 5 and 6) confirm that the second order surface model (eq. 1) can be used to describe the variation of the flame temperature (dependent variable) according to the variations of primary and secondary air section (independent variables) in all three burners used in this research. Observing the estimates of the coefficient of the regression model (table 7) and assuming a significance level of $5 \%$, it is possible to conclude that the constants $z_{0}$ and $e$ of the paraboloid model do not affect the flame temperatures of burner 1. Regarding the data of the flame temperature of burner 2, the $\mathrm{P}$ values calculated for the estimates of coefficients $c$ and $e$ are, respectively, 0.0921 and 0.3517 (table 7 ). Thus, assuming a significance level of $5 \%$, these coefficients are not different from zero. In other words, the squared values of the secondary air section and the interaction of primary and secondary air section that appear in the paraboloid model, do not influence the values of flame temperatures. Concerning the flame temperatures of burner 3 , the $\mathrm{P}$ value reported in table 7 for the estimates of the coefficients $a, c$, and $e$ are, respectively, $0.13,0.67$, and 0.42 , so for a significance level of $5 \%$ we can assume that they are not different from zero. No statistically significant difference was observed between the maximum predicted values of flame temperatures of the three burners in comparison.

The results obtained by the multiple regression analysis conducted on the values of flame length (tables 10 and 11), confirm a good fitting of the data to the adopted paraboloid model for burners 2 and 3. The value of the coefficient of determination calculated by the multiple regression on the flame length data of burner 1 is 0.79 . However the $\mathrm{P}$ value of analysis of variance of the multiple regression of flame length data of burner 1 (table 11), would seem to indicate that our second order surface model can be used to predict 


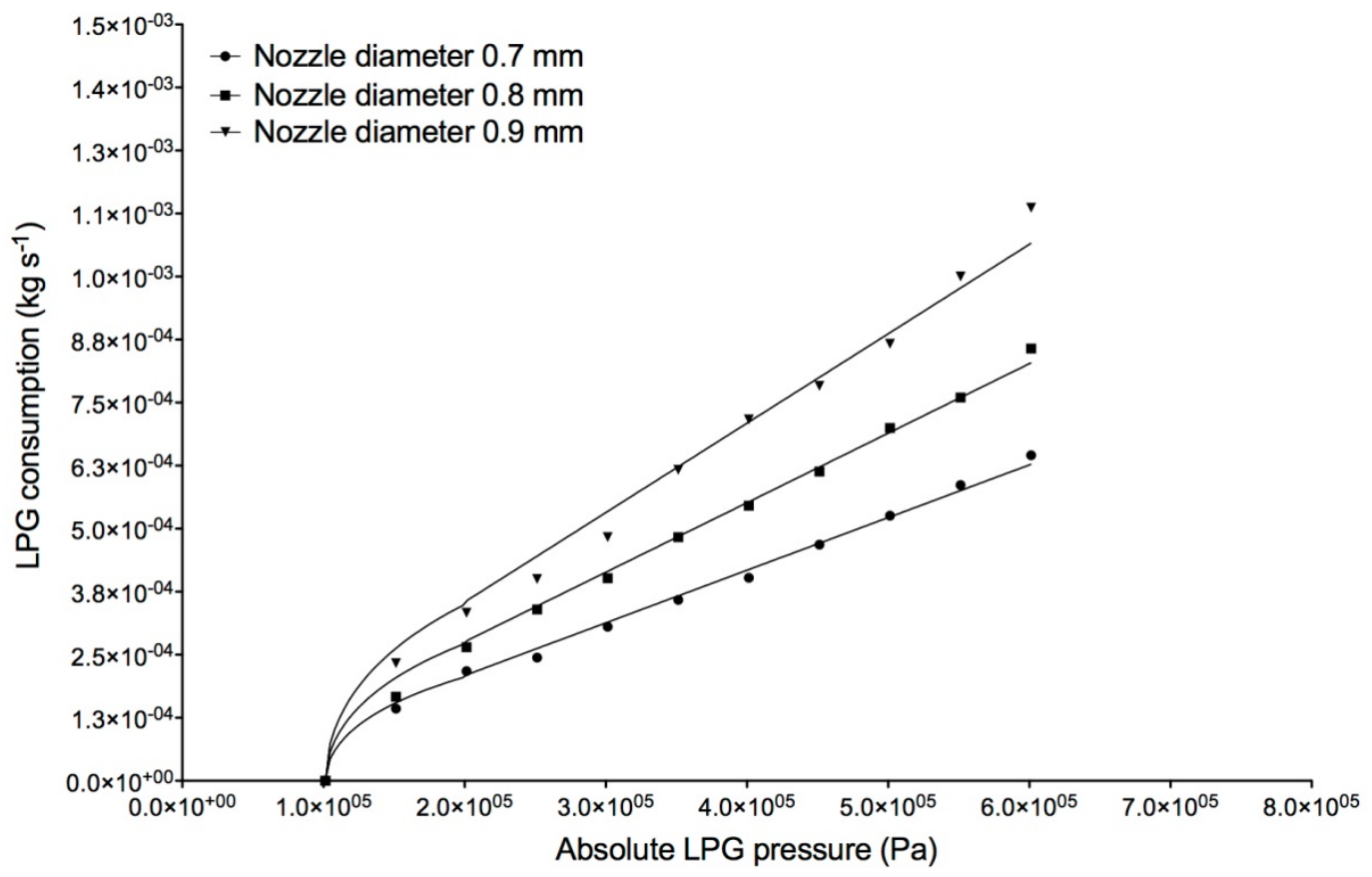

Figure 19. Non-linear regression with mixed outflow model (subsonic/sonic) based on the values of LPG consumption measured at different pressures and with different nozzle holes.

the variation of flame length according to the variation of primary and secondary air section, assuming a significance level of $5 \%$.

Observing the estimation of the coefficients of the function adopted for the multiple regression (table 12), according to the $P$ values, we can deduce that the variations in the primary air section should not affect the flame length variations. Regarding the influence of the secondary air

Table 15. Results of the non-linear regression of the values of LPG consumption at different LPG pressure conducted adopting the proposed mixed gaseous outflow model (subsonic/sonic).

\begin{tabular}{lccc}
\hline & \multicolumn{3}{c}{ Nozzle Hole Diameter $(\mathrm{mm})$} \\
\cline { 2 - 4 } Outflow Model Subsonic/Sonic & 0.7 & 0.8 & 0.9 \\
\hline Degrees of freedom & 10 & 10 & 10 \\
$\mathrm{R}^{2}$ & 0.9964 & 0.9959 & 0.9895 \\
Sum of squares (SS) & $1.382 \times 10^{-9}$ & $2.823 \times 10^{-9}$ & $1.243 \times 10^{-8}$ \\
Residual Standard deviation (Syx) & $1.176 \times 10^{-5}$ & $1.680 \times 10^{-5}$ & $3.526 \times 10^{-5}$ \\
\hline
\end{tabular}

Table 16. Runs test for the systematic deviation of the LPG consumption data from the mixed of gaseous outflow model (subsonic/sonic) adopted.

\begin{tabular}{lccc}
\hline & \multicolumn{3}{c}{ Nozzle Hole Diameter (mm) } \\
\cline { 2 - 4 } Outflow Model Subsonic/Sonic & 0.7 & 0.8 & 0.9 \\
\hline Points above the curve & 4 & 2 & 3 \\
Points below the curve & 6 & 8 & 7 \\
Number of "runs" & 4 & 4 & 4 \\
P (runs test) & 0.1905 & 0.5333 & 0.2833 \\
\hline
\end{tabular}

Table 17. Estimation of the discharge coefficient $C_{d}$ calculated by non-linear regression adopting a mixed gaseous outflow model (subsonic/sonic).

\begin{tabular}{lccc}
\hline \multirow{2}{*}{ Outflow Model Subsonic/Sonic } & \multicolumn{3}{c}{ Nozzle Hole Diameter (mm) } \\
\cline { 2 - 4 } \multicolumn{1}{c}{ Best-fit value $\mathrm{C}_{\mathrm{d}}$} & 0.9059 & 0.9 & 0.9 \\
Standard error & 0.008011 & 0.008760 & 0.9301 \\
Lower limit confidence interval (95\%) & 0.8881 & 0.8958 & 0.8978 \\
Upper limit confidence interval (95\%) & 0.9238 & 0.9349 & 0.9625 \\
\hline
\end{tabular}

section on flame length, the three burners behave differently. In the case of burners 1 and 2, decreasing values of secondary air section caused the flame length to increase. The opposite was observed for burner 3 . Regarding flame length data, a statistically significant interaction between secondary and primary air (coefficient $e$ ) was observed only in the case of burner 3 . Regarding the maximum predicted values of flame length, the only statistically significant difference at a level of 5\% was observed between burners 3 and 2 .

\section{Fuel CONSUMPTION}

The values of the coefficient of determination very close to 1 and the outcome of the statistical analysis of the run (tables 15 and 16), for all three curves examined, suggest that the model proposed for the gaseous outflow is suitable for describing the consumption of LPG detected during the trial. The low standard error values and the limited width of the 95\% confidence interval (table 16), calculated by non-linear regression according to a mixed gaseous outflow model (subsonic/sonic), support the goodness of fit and the precision of the estimated discharge coefficient of the three nozzles.

Table 18. Difference in the estimated values of the discharge coefficient and $95 \%$ confidence interval of the overlap test for the three nozzles.

$$
\begin{gathered}
\text { Difference of } \\
\text { Estimated }
\end{gathered}
$$

CI Overlap Test Values of Discharge LL 95\%

\begin{tabular}{cccc} 
Comparison & Coefficient & CI $^{[\mathrm{a}]}$ & $\mathrm{UL} \mathrm{95 \%} \mathrm{CI}^{[\mathrm{b}]}$ \\
\hline Nozzle 0.8 - Nozzle 0.7 & 0.0094 & -0.0139 & 0.0327 \\
Nozzle 0.9 - Nozzle 0.7 & 0.0242 & -0.0083 & 0.0567 \\
Nozzle 0.9 - Nozzle 0.8 & 0.0148 & -0.0184 & 0.0480 \\
\hline
\end{tabular}

[a] LL95\% 0.9 - Nozzle $0.8 \quad 0.0148 \quad-0.0184 \quad 0.0480$ difference;

[b] UL95\%CI is upper limit of the $95 \%$ confidence interval of the difference. 
No statistically significant differences were observed for the estimated values of the discharge coefficient of the three nozzles, which differed in terms of only the diameter of the orifice and were characterized by the same construction design (table 18). The estimated $\mathrm{C}_{\mathrm{d}}$ values are in agreement with those reported by Böhm and Böhm (1985), according to which the value of discharge coefficient for a gas nozzle can vary from 0.55 to 0.90 in relation to different types of construction, and can reach 0.97 for nozzles with tapered internal profiles.

\section{CONCLUSiOnS}

The flame temperature and length of a burner are some of the main parameters for the effectiveness of flame weeding. The production of high temperatures is crucial for biological effectiveness in terms of weed devitalization. This experiment showed that the inlet of secondary air affects the performances of these types of burner, both in terms of flame temperature and flame length.

In the case of the flame temperature, a consistent trend was observed for the three burners. Increases in the secondary air section value led to increments in the flame temperature. The influence of the secondary air section varied according to the type of burner in the case of flame length. Increases in the secondary air section value in burners 1 and 2 were related to decreases in the flame length. The opposite was observed for burner 3 .

To obtain an efficiency evaluation of the combustion of these burners it is necessary to conduct more specific studies in order to determine the exact value of the flow of LPG, primary and secondary air, which can ensure optimum combustion conditions. Our fuel consumption trial showed that the model proposed for the gaseous outflow is suitable for describing the LPG consumption detected during the trial. If the nozzle, operating pressure, and actual working time are known, our proposed model would be able estimate the LPG consumption of any flaming machine using burners with an external mixer.

\section{ACKNOWLEDGMENTS}

The authors greatly acknowledge funding from the regional government of Tuscany (Por-CREO PIROGESI project). The authors are also grateful to Roberta del Sarto and Calogero Plaia (Department of Agriculture Food and Environment, University of Pisa) for their contributions in these trials.

\section{REFERENCES}

Ascard, J. (1998). Comparison of flaming and infrared radiation techniques for thermal weed control. Weed Res., 38(1), 69-76. http://dx.doi.org/10.1046/j.1365-3180.1998.00073.x.

Böhm, A., \& Böhm, M. ((1985). Industria del gas, utilizzazione (Industrial gas utilization). In Nuovo Colombo Manuale dell'Ingengere $81 a 2$ volume (pp. 211-214). Milano, Italy: Edizione, Ulrico Hoepli.

Carter, L. M., Colwick, R. F., \& Tavernetti, J. R. (1960). Evaluating flame-burner design for weed control in cotton. Trans. ASAE, 3(2), 125-128. http://dx.doi.org/10.13031/2013.41139.
Datta, A., \& Knezevic, S. Z. (2013). Flaming as an alternative weed control method for conventional and organic agronomic crop production systems: A review. Adv. Agron., 118, 399-428. http://dx.doi.org/10.1016/B978-0-12-405942-9.00006-2.

de Rooy, S. C. (1992). Improved efficiencies in flame weeding. Ms thesis. New Zealand: Lincoln University Canterbury, Department of Natural Resources Engineering.

Ellwanger, T. C., Bingham, S. W., \& Chappell, W. E. (1973). Physiological effects of ultra-high temperatures on corn. Weed Sci., 21, 266-269.

Galbiati, L. (2005). Impianti di combustione. In P. Andreini (Ed.), Manuale dell'ingegnere meccanico (2nd ed., pp. 1461-1468). Hoepli Milano, Italy.

Hoffmann, M. (1990). Thermische Unkrautbekämpfung, Stand und Zukunftperspektiven, Zeitschrift für Pflanzenkrankheiten und Pflanzenschutz, Sonderheft XII. 439-445.

Kang, W. S. (2001). Development of a flame weeder. Trans. ASAE, 44(5), 1065-1070. http://dx.doi.org/10.13031/2013.6428.

Knezevic, S. Z., Stepanovic, S., Datta, A., Nedeljkovic, D., \& Tursun, N. (2013). Soybean yield and yield components as influenced by the single and repeated flaming. Crop Protection, 50, 1-5. http://dx.doi.org/10.1016/j.cropro.2013.03.014.

Laguë, C., Gill, J., Lehoux, N., \& Péloquin, G. (1997). Engineering performances of propane flamers used for weed, insect pest, and plant disease control. Appl. Eng. Agric., 13(1), 7-16. $\mathrm{http} / / / \mathrm{dx}$. doi.org/10.13031/2013.21581.

Motulsky, H. J. (1999). Analyzing data with GraphPad Prism. San Diego, Calif.: GraphPad Software Inc. Retrieved from www.graphpad.com.

Motulsky, H. J. (2007). Prism 5 Statistics Guide. San Diego, Calif.: GraphPad Software Inc. Retrieved from www.graphpad.com.

Motulsky, H. J., \& Christopoulos, A. (2003). Fitting models to biological data using linear and nonlinear regression. A practical guide to curve fitting. San Diego, Calif.: GraphPad Software Inc. Retrieved from www.graphpad.com.

Raffaelli, M., Fontanelli, M., Frasconi, C., Ginanni, M., \& Peruzzi, A. (2010). Physical weed control in protected leaf-beet in Central Italy. Renewable Agric. Food Syst., 25(01), 8-15. http://dx.doi.org/10.1017/S1742170509990287.

Raffaelli, M., Fontanelli, M., Frasconi, C., Sorelli, F., Ginanni, M., \& Peruzzi, A. (2011). Physical weed control in processing tomatoes in Central Italy. Renewable Agric. Food Syst., 26(2), 95-103. http://dx.doi.org/10.1017/S1742170510000578.

Raffaelli, M., Martelloni, L., Frasconi, C., Fontanelli, M., \& Peruzzi, A. (2013). Development of machines for flaming weed control on hard surfaces. Appl. Eng. Agric., 29(5), 663-673.

Rojey, A., Jaffret, C., Cornot-Grandolphe, S., Durand, B., Jullian, S., \& Valais, M. (1997). Natural Gas: Production, Processing, Transport. Paris, France: Editions Technip.

Systat. (2011). SigmaPlot version 12.0. San Jose, Calif.: Systat Software, Inc.

Ulloa, S. M., Datta, A., \& Knezevic, S. V. (2010). Growth stage impacts tolerance of winter wheat (Triticum aestivum L.) to broadcast flaming. Crop Protection, 29(10), 1130-1135. http://dx.doi.org/10.1016/j.cropro.2010.04.009.

Ulloa, S. M., Datta, A., Bruening, C., Neilson, B., Miller, J., Gogos, G., \& Knezevic, S. Z. (2011). Maize response to broadcast flaming at different growth stages: Effect on growth, yield, and yield components. European J. Agron., 34, 10-19. http://dx.doi.org/10.1016/j.eja.2010.09.002.

van den Bosch, C. J. H., \& Duijm, N. J. (2005). Chapter 2. Outflow and spray release. In C. J. H. van den Bosch, \& R. A. P. M. Weterings (Eds.), Methods for the Calculation of Physical Effects - Due to Releases of Hazardous Material (Liquid and Gases). The Hague, Netherlands: Publicatiereeks Gevaarlijke Stoffen. 